\title{
The regional consequences of authoritarian power-sharing: Politburo representation and fiscal redistribution in China
}

\author{
Yumin Sheng* \\ Wayne State University, Detroit, MI, USA \\ ${ }^{*}$ Corresponding author. E-mail: yumin.sheng@wayne.edu
}

(Received 30 April 2018; revised 18 February 2019; accepted 28 April 2019; first published online 21 June 2019)

\begin{abstract}
Much political economy research examines how higher-level political representation of the constituent jurisdictions affects resource redistribution among the lower-level units in democracies, but little work has probed the redistributive consequences of regional political representation under dictatorship. This study investigates the effect of membership for provincial officials in the Politburo of the single-ruling Chinese Communist Party (CCP) on fiscal resource flows between the central government and provincial governments in reform-era China. I find robust evidence that the provinces overseen by CCP Politburo members tended to remit more budgetary revenues to the center but did not receive larger central budgetary subsidies. This is consistent with a territorial logic of authoritarian power-sharing in single-party states, which suggests that the regionally selective presence at a collective ruling-party decision-making forum for subnational officials aims at tighter political control to help induce greater policy compliance from below.
\end{abstract}

Key words: Authoritarian power-sharing; China; redistribution; representation; resource extraction; subnational regions

\section{Introduction}

Does national-level political representation for the subnational units has redistributive consequences under dictatorship? In a democratic setting, more fiscal resources tend to flow to constituent units better represented at a higher level, as much political economy scholarship has long demonstrated (Ansolabehere et al., 2002; Rodden, 2002; Horiuchi and Saito, 2003). Growing attention has turned to the role of pseudo-representative political institutions such as elections, political parties, and parliaments in nondemocratic systems (Gandhi and Przeworski, 2007; Magaloni, 2008; Wright, 2008; Malesky et al., 2012; Manion, 2015; Truex, 2016). ${ }^{1}$ Little work, however, has examined the consequences for intergovernmental resource flows of membership for subnational leaders in a nationallevel policy-making institution in authoritarian states.

One strand of the authoritarian power-sharing thesis suggests that such political representation under single-party dictatorship might constitute tools of appeasement and cooptation employed by the reigning national autocrats vis-à-vis their allies but potential rivals within the regime (Gandhi and Przeworski, 2006; Svolik, 2012). Thus, subnational officials seated at a top national policy forum should be able to secure more policy pork by retaining more local fiscal resources or bringing greater central fiscal largesse to the local jurisdictions they oversee. If such power-sharing is also aimed at helping the national autocrats keep a tighter grip over selected subnational regions (Sheng, 2009), membership for regional leaders at the ruling-party decision-making organ might not necessarily facilitate the inflows of central fiscal assistance; it might even ease revenue extraction from the targeted regions.

\footnotetext{
${ }^{1}$ Following much of this recent literature, for the purposes of this essay, I use terms such as 'dictatorship', 'nondemocracy', 'autocracy', and 'authoritarianism' synonymously and interchangeably. 
This study empirically tests these theoretical predictions in the context of contemporary China under the rule of a single political party - the Chinese Communist Party (CCP). Employing a subnational research design and panel error-correction model including province/year fixed effects and a spatial lag, it investigates how membership for provincial officials in the Politburo of the ruling CCP affected provincial fiscal contributions to the central government and central budgetary subsidies for the provinces during 1995-2004, often characterized as the heyday of breakneck economic growth and liberalization at the expense of rising regional disparity (Hung, 2015; Dickson, 2016). I find strong and robust evidence that, other things being equal, Chinese provinces ruled by the CCP Politburo members tended to remit more revenues to the central government. Meanwhile, Politburo membership for provincial officials did not translate into larger fiscal subsidies from the central government, which were generally directed at provinces with higher budget deficits. In the short term, sending a Politburo member to lead a province was associated with an immediate increase of about 62 million RMB (1977 constant value) of provincial budgetary remittances to the central government, over $11 \%$ of the average annual total provincial contributions. Over the sample period, posting a Politburo member in a province would translate into an increase of over 152 million RMB of budgetary remittances to the center.

These findings support the notion that power-sharing by national autocrats via selective seating of subnational officials at a collective decision-making forum of the single-ruling party could help ease fiscal resource extraction from, but might not facilitate central government fiscal largesse for, the 'represented' regions. This study thus contributes to the literature on the 'varieties' of authoritarianism in comparative politics by highlighting a territorial dimension of authoritarian power-sharing largely neglected in the existing efforts to explain the logic of authoritarian single-party rule (Brownlee, 2007; Gandhi, 2008; Magaloni, 2008; Svolik, 2012).

Evidence of greater compliance with central fiscal extraction by Politburo members working in the provinces in the post-1994 era based on quantitative evidence is consistent with the more qualitative scholarship that suggests that provinces ruled by Politburo members such as Shanghai tended to be subject to particularly heavy fiscal burdens from the center even throughout the pre-1994 years (White, 1989; Whiting, 2001). They are consonant with media reports that these provinces were more receptive to the center's fiscal centralization initiative on the eve of the fiscal reform of 1994 (Zhao, 2003). They are also in line with other systematic research that links Politburo membership for provincial officials with lower fixed-asset investment growth and inflation rates in the provinces they led, as preferred by the Chinese central government (Huang, 1996; Huang and Sheng, 2009). This study thus contributes to a growing literature in recent years that seeks to illuminate the various aspects of authoritarian single-party rule in reform-era China (Landry, 2008; Chen, 2012; Wallace, 2014; Manion, 2015; Dickson, 2016; Truex, 2016), but I have focused on how regional presence in the Politburo of the ruling CCP has affected fiscal flows between the center and the provinces. To my best knowledge, this is the first study that examines the determinants of both fiscal extractions from, and inflows of central fiscal subsidies into the provinces during this period.

The remainder of the essay is organized as follows. I first briefly survey the existing literature on territorial political representation and regional resource redistribution under democracy and discuss the redistributive implications of authoritarian power-sharing along the territorial dimension under dictatorship in Section 2. I then sketch the Chinese context before introducing the data on the dependent and independent variables and summarizing the main hypotheses to be tested in Section 3 . In Section 4, I present the results of the empirical analysis. By way of conclusion, I draw the broader implications in Section 5.

\section{Territorial representation and resource redistribution}

\subsection{Representation and redistribution under democracy}

Genuine political representation seems only feasible in democratic states. Not surprisingly, most existing research on the redistributive consequences of territorial representation focuses on democracies. 
A fundamental concern is how unequal political representation at a higher-level legislative forum might engender unequal shares of resources for different constituent geographic units. ${ }^{2}$ Drawing on theories of legislative bargaining, for instance, Knight (2008) argues that units overrepresented on a per capita basis are more likely to benefit from agenda-setting powers and are cheaper, more attractive partners to be included in the 'winning coalitions' of legislative deal-making. Thus, politically overrepresented member regions often receive more economic resources from higher-level legislative bodies.

Empirical evidence has mostly come from the US Senate, where the equal allocation of two members to each state has created notorious overrepresentation by small states (on a per capita basis). For example, Atlas et al. (1995) find that unequal per capita representation in the US Senate resulted in unequal per capita federal net spending during the 1972-1990 period. Similarly, Lee (2000) shows that less populous states enjoying greater representation in the Senate received disproportionately larger shares of federal surface transportation funds on a per capita basis in the 1990s. ${ }^{3}$ Evidence of disproportionate resource dispensation to overrepresented constituent regions is not confined to American federal politics or the sole settings of the United States.

Indeed, Ansolabehere et al. (2002) have demonstrated that American counties with more seats per capita in state legislatures also received higher per capita monetary transfers from the states. Counties with reduced legislative seats through court-ordered redistricting in the 1960s consequently received declining state money. Meanwhile, for Horiuchi and Saito (2003), Japanese municipalities with more seats per capita in the Japanese Diet witnessed greater inflows, on a per capita basis, of central government subsidies and, following the 1994 electoral reform, those losing Diet seats also saw dwindling central inward transfers.

Even in quasi-federations composed of sovereign states, a seat at the table can matter if voting by members is required for policymaking. Smaller member states of the European Union that were overrepresented in the European Parliament and the Council of Ministers often received greater EU fiscal transfers during 1977-1999 (Rodden, 2002). This echoes Isenman's (1976) earlier detection of a similar 'bias' in allocation of international aid, largely because smaller states enjoy equal voting power and can be more effectively, in terms of per capita assistance, 'bought off at an international voting forum - the United Nations General Assembly. In short, overrepresentation at a democratic legislature or a supranational arena where decision-making involves voting translates into more inward monetary transfers for constituent units.

\subsection{Power-sharing, representation, and redistribution under dictatorship}

Much less is known about political representation in nondemocratic states where meaningful legislative voting hardly exists. The dearth of scholarly attention is understandable. Authoritarian representation is an oxymoron; establishment of rubber-stamping 'representative' institutions by autocrats rarely goes beyond symbolic window-dressing. A growing body of new scholarship on the political economy of dictatorship, however, has started to question this long-held view on the nature of authoritarian political institutions.

One strand of research revolves around the role of authoritarian power-sharing via pseudodemocratic political institutions in dictatorship such as parliaments. A major thesis highlights how autocrats could set up nominal legislatures for the very purpose of stabilizing and prolonging their rule. While diluting the absolute power of the autocrats, such authoritarian power-sharing via limited political representation might ease the co-optation of the opposition. For instance, Gandhi and Przeworski (2007) conjecture that some dictators allow the presence of legislatures to tame potential opposition from the civil society. Likewise, Wright (2008) argues that dictators install legislative institutions either as a credible constraint on themselves to attract investment or as an appeasement tool to

\footnotetext{
${ }^{2}$ For an excellent discussion of electoral malapportionment in a global context, see Samuels and Snyder (2001).

${ }^{3}$ Others (e.g., Berry et al. 2010), meanwhile, focus on the mediating role of the President and argue that US federal spending tends to go to districts and counties represented by legislators sharing the President's party label.
} 
neutralize the opposition. Similarly, Malesky et al. (2012) have shown how the national parliament in contemporary Vietnam largely serves the interests of the ruling communist party. Scholarship along these lines, however, rarely probes the nature or consequences of the territorial dimension of representation in an authoritarian legislature. ${ }^{4}$

Meanwhile, a related but distinct thrust of research has focused on power-sharing and representation within one type of dictatorship - single-party authoritarian regimes. There are two main variants, both with regional redistributive implications. The first assumes that the leaders under single-party authoritarianism are not as monolithic as commonly perceived. In fact, the most lethal threats to autocrats arise from within due to the fundamental problem of uncertainty and prevalence of violence as the final arbiter of conflicts in the absence of institutionalized rules under authoritarianism (Svolik, 2009). Internal power-sharing at a collective policy-making forum within the single-ruling party such as its Politburo might help the reigning autocrats secure the support of ambitious allies (but potential rivals) within the regime, some of whom work at the subnational level. This could improve reciprocal monitoring and increase mutual assurances among the top autocrats and their colleagues, thus help maintain regime stability and preserve their autocratic rule (Gandhi and Przeworski, 2006; Svolik, 2012).

Because colleagues offered Politburo seats essentially constitute a crucial bloc of the 'Selectorate' deciding the fate of reigning autocrats (Shirk, 1993), they might be rewarded with a variety of policy pork or rents by the autocrat, if only as a bribe in exchange for their continuing loyalty (Bueno de Mesquita et al., 2003). Under this logic, regional governments overseen by sitting ruling-party Politburo members might be able to get away with a less cumbersome fiscal burden toward the central government, or even be lavished with larger central fiscal assistance for their local jurisdictions, thus yielding more resources at their own disposal.

The second variant of this body of research assumes a relatively unified national authoritarian leadership in single-party states (Geddes, 1999), especially when it comes to the common need to confront challenges arising along the territorial dimension from the regions beyond the national capital, as dictators from Qaddafi of Libya to Assad of Syria must have become painfully aware of. This should be of greater relevance to authoritarian states governing a vast territory like China (Chung, 2016). It suggests that power-sharing and representation at the collective decision-making institutions such as the Politburo within the single-ruling party by including regionally-based officials enables the autocrats who run the central government to pursue territorially targeted control in order to preserve their national rule.

Employing their personnel control over the regional government leadership - the nomenklatura powers afforded by the single ruling party (Harasymiw, 1969), the national autocrats can send trusted allies that are seated at the ruling-party Politburo to govern selected subnational regions (Sheng, 2009). Inducted into the national core leadership of the regime, regionally-based leaders with a ruling-party Politburo membership should have more 'encompassing' interests in the success of, and greater incentives to comply with, the policy priorities of the national autocrats than their counterparts who are not Politburo members (Huang, 2002).

In the fiscal realm, such a greater inclination for policy compliance by regional officials who are sitting Politburo members might lower the 'transaction costs' (Levi, 1988) of central government revenue extraction efforts from the better 'represented' regions they lead. If such authoritarian powersharing aims at tighter control of the selected regions, rather than at simply appeasing allies or disgruntled rivals of the autocrat, subnational regions overseen by close lieutenants of the national autocrats and thus enjoying greater 'political representation' at a national-level policymaking forum might not necessarily be rewarded with greater inflows of fiscal resources from the central government.

\footnotetext{
${ }^{4} \mathrm{An}$ influential line of literature has also long grappled with the evolving role of the legislature in the Chinese polity. See, for instance, O'Brien (1990) and Truex (2016) on the National People's Congress, Manion (2015) and Xia (2008) on the local people's congresses at the various levels. Little scholarship, however, has examined the (even nominal) representation of the constituent units at the legislative body and its redistributive consequences from a territorial angle, my focus here.
} 
In sum, little research exists on the redistributive consequences of authoritarian power-sharing and political representation along the territorial dimension in single-party autocracies. The logic of authoritarian internal power-sharing suggests that offering a Politburo seat for regional leaders to buy off the support and loyalty of political allies but potential rivals of the national autocrats might hinder central fiscal extraction from below, but ease inflows of fiscal assistance for the regions. An alternative territorial logic on authoritarian power-sharing, in contrast, posits that the assignment of the ruling-party Politburo members could facilitate fiscal resource extraction by the central government without necessary fiscal compensation for the regions. To the best of my knowledge, no systematic work has explicitly tested the effect of ruling-party Politburo membership for regional officials on the extent of central fiscal extraction from and fiscal compensation for the subnational regions in an authoritarian setting. I try to start tackling this scholarly lacuna by turning to the case of contemporary China.

\section{The case of China}

\subsection{The post-1978 context}

Communist rule in China in the reform-era is perhaps best characterized as a single-party regime (Geddes, 1999). Until the most recent power centralization under President Xi since late 2012 (Economy, 2014; Li 2016), post-Mao China had witnessed the gradual emergence of a collective leadership and the increasing institutionalization of norms of retirement and peaceful and orderly leadership succession within the CCP (Manion, 1993; Wang and Vangeli, 2016). ${ }^{5}$ More important for our purposes, the national leaders of the CCP are politically dominant vis-à-vis the provincial leaders (Lieberthal, 2003). Above all, the national leaders have exercised the nomenklatura powers and monopolized the personnel appointments over the provincial leaders, via ruling party institutions such as the central Department of Organization (Huang, 1996; Landry, 2008). Combined with their predominance in the ruling-party Politburo, such personnel powers have enabled the CCP national leaders to send CCP Politburo members to rule the provinces.

The Politburo, composed of around two-dozen members of the CCP Central Committee (CC), is the sort of 'collegial' forum within the ruling party responsible for the country's major domestic and foreign policymaking. Its members constitute the national core leadership of the party and government. The Chinese national leaders, who run the CCP national offices and the central government and command the military, dominate the Politburo (Shambaugh, 2003). Only they join the smaller and even more exclusive Standing Committee of the Politburo at the apex of political power in China. ${ }^{6}$ The national leaders have always occupied the overwhelming majority of Politburo seats in this period (Sheng, 2005), over 70\% in any year during 1978-2017. In late 2017, for example, national leaders occupied 19 out of 25 seats $(76 \%)$ in the newly elected Politburo of 19th CC of the CCP. The recent decades also witnessed a rising share, from nil during 1981-1984 to $24 \%$ of Politburo membership for provincial officials as of early $2018 .^{7}$

Meanwhile, provincial governments in China do not have the independent authority to define their own tax base or set the tax rates in their own jurisdictions, but they have played an important role in the fiscal flows between the provinces and the central government. They were directly involved with the center's revenue collection in the provinces before the 1994 fiscal reform that established the

\footnotetext{
${ }^{5}$ Indeed, there is also evidence that the personnel appointment power of the CCP General Secretary during this period was not unconstrained (Zeng, 2018), consistent with the notion of a collective leadership in charge.

${ }^{6}$ The national leaders in China are CCP Politburo members who work at the national level.

${ }^{7} \mathrm{CCP}$ national leaders can send Politburo members to work in the provinces or promote incumbent provincial officials to Politburo membership. Since the national leaders monopolize the personnel powers, provincial officials newly elevated into the Politburo can only remain in the provinces at the sufferance of the former. For practical purposes, this is equivalent to sending sitting Politburo members to work in these provinces. Information on the Politburo of the 19th CCP Central Committee is available: http://www.news.cn/politics/leaders/, accessed on 2 April 2018.
} 
center's own tax collection agencies nationwide (Wong et al., 1995). ${ }^{8}$ Since then, such direct extraction by the provincial governments on behalf of the center has diminished, but they still influence the collection of central taxes within their jurisdictions (Yang and Jiao, 2001). ${ }^{9}$ More important, the provincial governments have helped determine the terms of their formal fiscal obligations to the center and the amount of central fiscal compensation for the provinces in the first place.

Under pre-1994 fiscal contracting, the provincial governments often sought to bargain with the national leaders over the amount of revenues they could retain in the provinces in their fiscal contracts with the central government (Jin et al., 2005). The fiscal reform of 1994 to institutionalize centralprovincial fiscal ties and infuse more certainty in expectations over how much the central government can take from the provinces and how much the provinces need to deliver to the central coffer has not obviated such attempts at influence from below. The provincial governments have continued to haggle with the center over the amount of provincial budgetary remittances to the center or the size of central fiscal subsidies to the provinces (Chang 1999; Zhao 2003). In short, the provincial governments still play a key role in central-provincial fiscal flows after the 1994 fiscal reform.

Existing empirical research has examined how provincial presence at the Politburo could affect the flows of central fiscal resources into, rather than resources out of the provinces in post-1994 China. Using a dummy variable on whether a sitting Politburo member happened to serve in a province as a proxy for provincial lobbying power, Wang (2004: 232-234) finds that Politburo membership for provincial officials was not a significant predictor of central subsidies for the provinces in 1998 . Likewise, Fan and Zhang (2011) do not detect any significant effect of Politburo membership for provincial officials on central fiscal subsidies to the provinces during the period of 1999-2009. In this study, I take advantage of a time-series cross-sectional dataset on annual provincial presence at the CCP Politburo and yearly central-provincial formal fiscal flows during the post-1994 period to test how Politburo membership for provincial leaders affected central fiscal extraction from, and central fiscal subsidies into the provinces in China.

\subsection{Data}

The unit of analysis is province/year. Relatively consistent provincial-level budgetary data have become available since the 1994 fiscal reform. I use two separate dependent variables. Remittance is the annual real per capita budgetary remittances (at constant $1977 \mathrm{RMB}$ ) to the central government from each province during the period of 1995-2004. Subsidy is the annual real per capita central subsidies for each province in the same period. ${ }^{10}$ The sample only extends to 2004 as China's provincial-level economic data - such as gross-domestic product (GDP), a crucial control variable - have been reported with new statistical standards since 2005, making them potentially inconsistent with those from earlier years. ${ }^{11}$

Moreover, the 1995-2004 period provides an especially interesting empirical setting for testing the authoritarian power-sharing thesis at the subnational level, and in particular, the effect of CCP

\footnotetext{
${ }^{8} \mathrm{~A}$ new round of government restructuring announced in early 2018, however, plans to re-merge the local and central tax collection agencies nationwide, according to http://www.xinhuanet.com/english/2018-03/13/c_137035768.htm, accessed on 19 April 2018.

${ }^{9}$ National tax bureaus located in the provinces are still susceptible to local pressures because their personnel working/living in the localities are dependent on the variety of amenities controlled by the local governments. Thus, problems of tax evasion and tax arrears in the provinces during the early post-1994 period were often more serious for taxes accruing to the center than those going to the local coffers as 'the local tax bureaus enjoyed tax collection priorities over the branches of the national tax bureau' in the localities (Wang, 1997: 813-814).

${ }^{10}$ I use data on fiscal subsidies that subtract the less discretionary, formula-based tax rebates. Data on subsidies and remittances are from Zhongguo Caizheng Nianjian Bianji Weiyuanhui (1996, 1997-2004, 2005); data on tax rebates are from Caizhengbu Difangsi (1996, 1998); Caizhengbu Guokusi and Caizhengbu Yusuansi (2002, 2003, 2005, 2006); and Caizhengbu Yusuansi (1998, 1999, 2001a, 2001b).

${ }^{11}$ In 2005 the Chinese government announced the abolition of the agricultural tax (a local tax), reducing mostly revenues of the local governments but affecting central-provincial fiscal flows in subsequent years. I thank John Kennedy for pointing this out for me.
} 
Politburo membership for provincial officials on central-provincial fiscal flows in China. These years had largely been presided over by Jiang Zemin who as the CCP party chief had pursued runaway economic growth and liberalization, often at the expense of yawning regional inequality among the provinces. The Chinese central government only started seriously addressing this via greater redistributive efforts in favor of inland provinces that had not been faring as well and other previously neglected social strata such as the peasants in an effort to build a 'harmonious society' via 'scientific development' under Jiang's successor Hu Jintao (Lam, 2006; Hung 2015). Although Hu formally took over as the party chief in late 2002, Jiang did not retire as the military chief and give up the most important political power until September of $2004 .^{12}$

Meanwhile, Jiang Zemin has also been known for his putative 'regional favoritism' by promoting former lieutenants from Shanghai where he had worked in the late 1980s, the so-called 'Shanghai gang' (Li, 2002) and might have subsequently lavished localities like Shanghai with preferential fiscal policies. During these years, in other words, the Chinese central government could have been especially susceptible to fiscal lobbying efforts from subnational regions overseen by officials in Jiang's power-sharing orbit. Focusing on this period thus can help us mitigate problems in empirical estimations arising from possible structural policy shifts following changes of China's national leadership while providing the empirical setting of a 'most likely case' (Gerring, 2007) linking authoritarian power-sharing to fiscal rewards and compensation at the regional level.

There are two additional advantages in using the fiscal flow data. First, unlike data on marginal revenue retention rates in fiscal contracts between the Chinese central and provincial governments for the pre-1994 years (Jin et al., 2005), or data on local government budgetary revenues (Lü and Landry, 2014), data used in this study directly measure the actual amount of fiscal flows between the central government and the provinces, consistent with the more direct measures of resource redistribution in other settings.

Second, there is substantial variation in how much the provinces contributed to and received from the central fiscal coffers, both across the provinces and over the years. In Figure 1, I present summary data on the dependent variable for the sample period of 1995-2004. For instance, on average, Shanghai was the largest contributor, sending in about $232 \mathrm{RMB}$ per capita each year; Gansu had contributed the least to the central government, remitting on average barely one RMB per capita annually. On the receiving end, Tibet was the most subsidized province, taking in over $686 \mathrm{RMB}$ per capita on an annual basis while Jiangsu was only able to get less than 19 RMB per capita a year on average. There was also considerable cross-year variation for the provinces. It is such spatial and temporal variation that I seek to explain in this study.

As noted, the fiscal reform of 1994 to institutionalize intergovernmental revenue sharing has failed to remove the element of arbitrariness in the central-provincial fiscal ties. The sum of remittances from and central subsidies for each province has remained subject to negotiations in the post-1994 years (Chang, 1999; Zhao, 2003). Ceteris paribus, a higher Remittance value indicates more provincial budgetary revenue contributions to (a larger extent of formal fiscal extraction from the provinces by) the central government. Likewise, a higher value of Subsidy indicates greater fiscal compensation by the central government for the provinces. Ideally, one would want to examine both the formal and informal aspects of central-provincial fiscal flows, but systematic information on the latter is scarce. I thus focus on the formal fiscal flows.

In any year, only the top official, the yibashou (number one official, the provincial party secretary with the final say over policy matters in the province) from a few provinces was seated at the CCP

\footnotetext{
${ }^{12}$ Most important for our purposes, due to Jiang's possible role in 'stacking' the new Politburo with his 'allies' at the 2002 Party Congress when Hu became the party chief, Fewsmith (2003) simply calls it the 'succession that didn't happen.' Perhaps not coincidentally, Hu's own redistributive policy initiatives such as 'scientific development' also began to be publicized in the country sometime in 2004 (Fewsmith 2004), while abolition of agricultural tax was announced in 2005, as noted. If the example of Deng Xiaoping, Jiang's predecessor as commander in chief and China's top leader until his retirement in 1989 when Jiang took over, is any indication, one can argue Jiang had remained as the top leader of China at least until the fall of 2004 .
} 
Panel A. Provincial Fiscal Remittances to the Central Government, 1995-2004
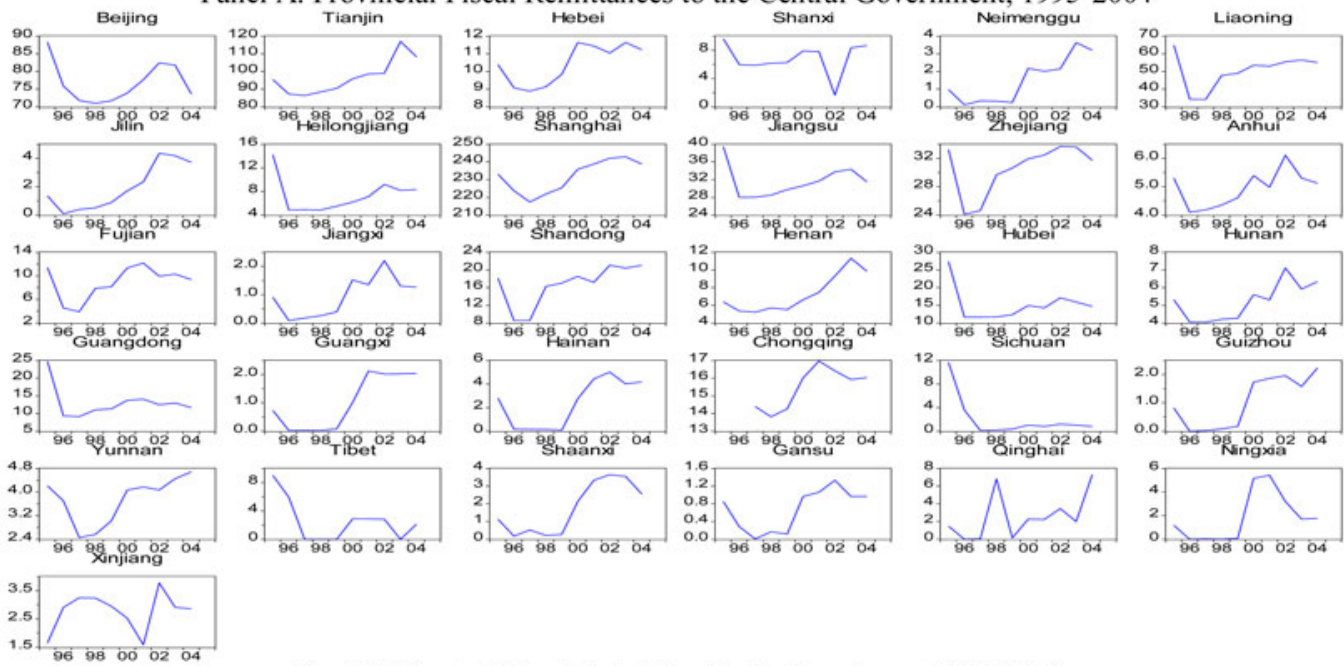

Panel B. Central Fiscal Subsidies for the Provinces, 1995-2004
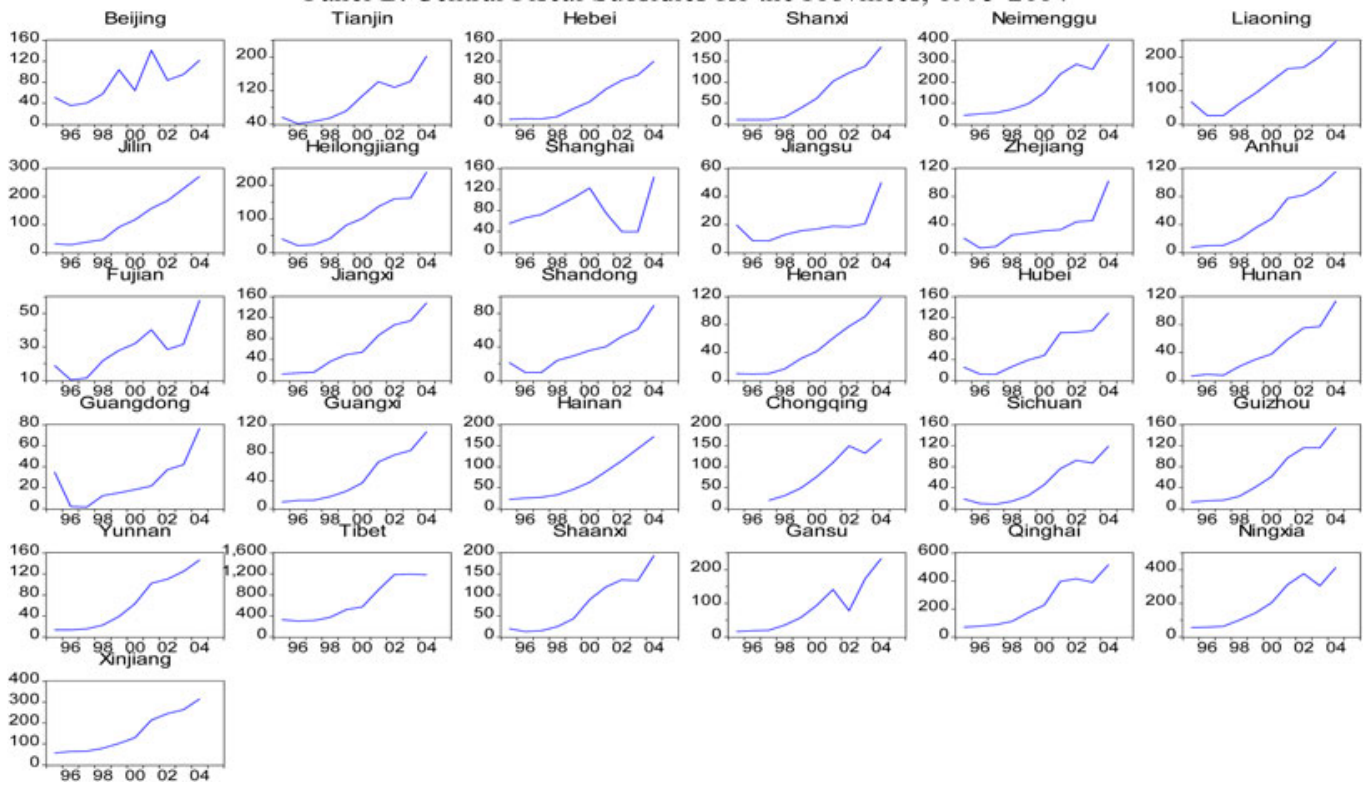

Figure 1. Data on the dependent variable.

Source: Data on subsidies and remittances are from Zhongguo Caizheng Nianjian Bianji Weiyuanhui (1996, 1997-2004, 2005); data on tax rebates are from Caizhengbu Difangsi (1996, 1998), Caizhengbu Guokusi and Caizhengbu Yusuansi (2002, 2003, 2005, 2006), and Caizhengbu Yusuansi (1998, 1999, 2001a, 2001b).

Note: Data in Panel (A) refer to real annual provincial per capita budgetary revenue remittances to the central government (constant 1977 RMB); data in Panel (B) refer to real annual provincial per capita budgetary subsidies (excluding formula-based tax rebates) from the central government.

Politburo. What distinguishes the provinces most is not how much Politburo presence a province had in a year, but whether it was at all represented at the Politburo. For my analysis, I mainly employ a dummy variable indicating whether a Politburo member ever served in a province during a year as the independent variable, denoted as Politburo. For robustness checks, I use Politburo Share, the percentage share of Politburo membership for incumbent officials for a province in a year, calculated on the basis of monthly data on personnel movements. The data on the independent variable are 


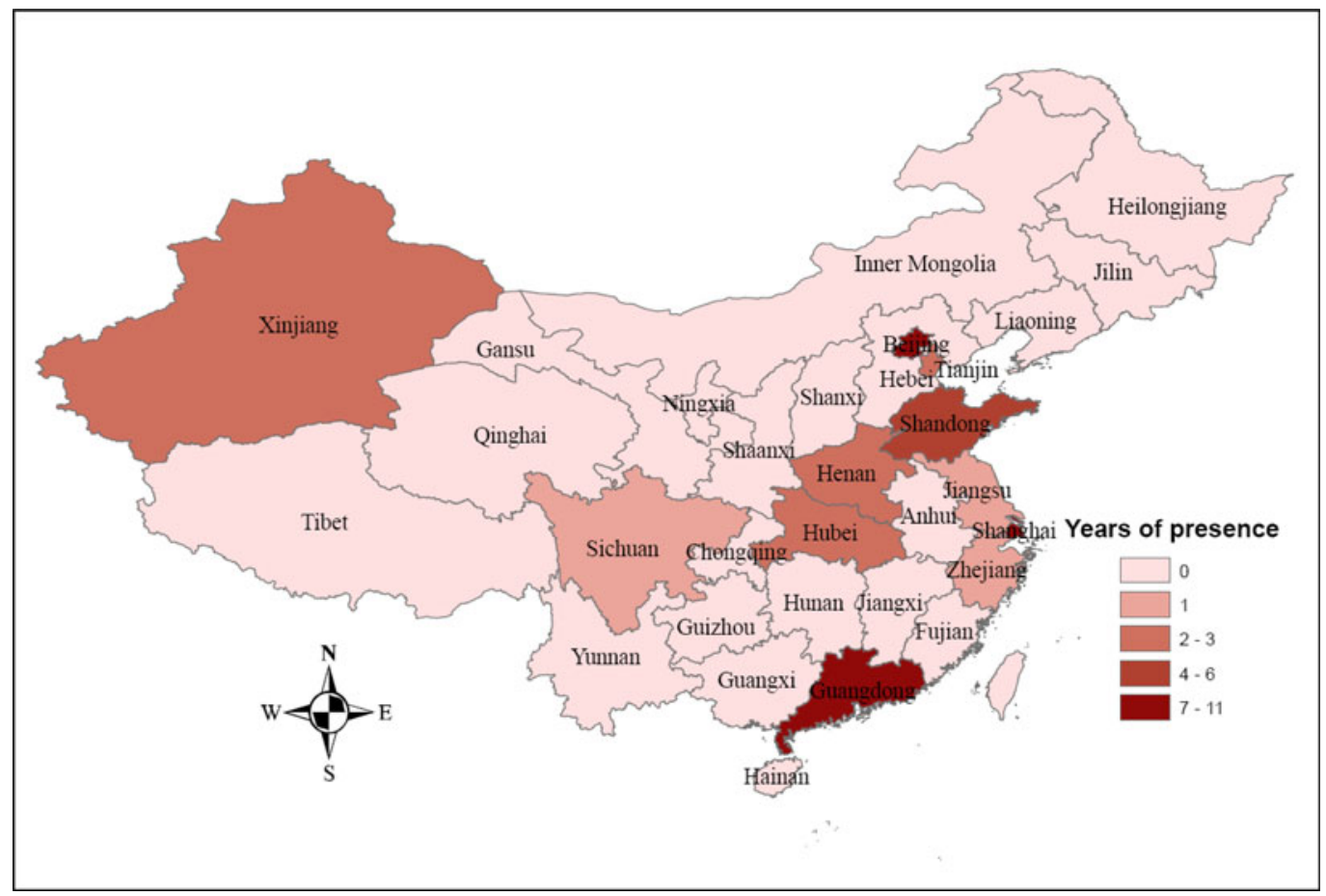

Figure 2. Data on the independent variable.

Source: Sheng $(2009,80)$.

Note: Data refer to total number of years during 1994-2004 in which a CCP Politburo member served in a province. The provinces/years ruled by a Politburo member were Beijing/1994-2004, Guangdong/1994-2004, Henan/1997-1998, Hubei/2002-2004, Jiangsu/2002, Shandong/1994, 1997-2002, Shanghai/1994-2004, Sichuan/2002, Tianjin/2002-2004, Xinjiang/2002-2004, and Zhejiang/2002.

summarized in Figure 2. They cover 1994-2004 due to the need for lagging the independent variable in later empirical estimations (more below).

\subsection{Hypotheses}

The logic of authoritarian internal power-sharing suggests that China's national leaders might allow provincial officials seated at the Politburo to keep more fiscal resources in their local jurisdictions or send more central fiscal assistance to the provinces overseen by these officials. Politburo members working at the provincial level are often powerful autocrats in their own right within the regime, often with close ties to patrons at the national level not necessarily holding formal jobs (Unger and Dittmer, 2002). They could be either close allies or potential rivals (or both) of the reigning CCP national leaders whose loyalty and support will be crucial for regime stability and survival. Indeed, when occasionally Politburo members based in the provinces - Chen Xitong of Beijing in the 1990s, Chen Liangyu of Shanghai in the 2000s, and Bo Xilai in 2012 - did become openly unruly and had to be removed on charges of corruption, it could undermine the legitimacy of the CCP and threaten the rule of the CCP national leaders ( $\mathrm{Li}, 2016$ ).

Access to more public fiscal resources not only could help these officials provide more public goods in the localities and build a stronger performance record for future promotions to the national-level offices. It could also engender immense opportunities for embezzlement and other rents for these officials as well as their families and cronies, often essential to sustaining political loyalty in a dictatorship (Bueno de Mesquita et al., 2003). To woo their loyalty and support, therefore, China's national leaders might be interested in lavishing the provinces led by these Politburo members with more fiscal 
resources via providing greater fiscal assistance or imposing on them less onerous fiscal obligations toward the central government.

Meanwhile, the mounting fiscal woes for the provinces in this period should also increase the incentives of all provinces to lobby the central government for fiscal assistance. As the 1994 fiscal reform drastically centralized tax collection in China, dwindling revenue shares but soaring spending mandates have constrained the fiscal capacity of all provincial governments increasingly dependent on central fiscal subsidies (Landry, 2008). Indeed, central fiscal subsidies financed on average nearly $48 \%$ of local (provincial and below) government budgetary spending during 1994-2004, compared with only 23\% during 1990-1993 (Zhongguo Caizheng Nianjian Bianji Weiyuanhui, 2005: 361-365). Provincial party chiefs who were Politburo members should be more effective at negotiating with the central government to keep more local fiscal resources in their own hands or bring in more central fiscal resources. I thus hypothesize:

Ha. Provinces ruled by Politburo members tended to remit less budgetary revenue to, or receive more fiscal subsidies from the Chinese central government than other provinces, other things being equal.

Politburo membership for provincial officials should thus be associated with lower provincial revenue remittances to, or greater central fiscal assistances from the central government. We expect a negative sign for the coefficient of the independent variable if Remittance is the dependent variable and a positive sign when Subsidy is the dependent variable in the empirical analysis.

Under an alternative territorial logic of authoritarian power-sharing, in contrast, regionally selective Politburo membership for provincial officials could facilitate fiscal extraction from the targeted provinces without necessarily easing greater inflows of central fiscal resources. Politburo members based in the provinces tend to regard themselves as part of the national core leadership (Huang, 2002). Indeed, provincial party secretaries who were Politburo members were much more likely to be promoted to higher offices at the national level than those who were not $-83 \%$ of the Politburo members vs $14 \%$ of the non-Politburo members during 1978-2005 (Sheng, 2010). The future of these officials seems to lie more with the national leaders, than with the localities where they were serving. Compared with provincial leaders who are not Politburo members, ceteris paribus, these officials are more sympathetic with the policy outlook of, and have greater incentives to comply with the policy preferences of, the CCP national leaders.

After a secular decline in revenue shares going to the central government, the CCP national leaders implemented the 1994 fiscal reform in order to centralize revenue collection, and to help keep the country together and themselves in power (Naughton and Yang, 2004; Chung, 2016). Arguably, the relative success of such fiscal centralization, at least in the eyes of the central government, ${ }^{13}$ had paved the way for the later regional 're-balancing' favoring the inland provinces faring less well during the reform era (Hung, 2015). Remitting more revenues to the central government enhances the fiscal standing of and clearly is in the interest of the central government. If one key goal of CCP's national leadership in dispatching Politburo members to rule selected provinces is to help induce policy compliance from below (Sheng, 2009), Politburo members working in the provinces should perhaps be more conscientious in fulfilling the task entrusted to them by their senior colleagues in the Politburo (Standing Committee). They should work harder for ensuring the delivery of provincial budgetary revenue remittances to the central fiscal coffers. As Politburo members, even Chen Xitong, Chen Liangyu, and Bo Xilai did not seem to have slacked in remitting revenues to the central government. ${ }^{14}$ They might also bargain less

\footnotetext{
${ }^{13}$ The share of total government revenues for the central government rose from 30\% during $1978-1993$ to over 52\% during 1994-2004 while its spending share dropped from 42 to 30\% (Zhongguo Caizheng Nianjian Bianji Weiyuanhui 2005: 361-365).

${ }^{14}$ Beijing's record per capita remittance of 88.3 RMB (1977 value) in 1995, the year when Chen Xitong was arrested, was never surpassed by his successors throughout 1995-2004. Shanghai's average remittance increased from about 230 RMB during 1995-2002 to about 258 RMB during 2003-2006 when Chen Liangyu was its party chief. While Bo Xilai had largely ruled
} 
assiduously on behalf of the provinces over the terms of their formal fiscal obligations to the center or the amount of fiscal compensation from the central government. I thus hypothesize:

Hb. Provinces ruled by Politburo members tended to remit more budgetary revenue to, and might not necessarily receive more fiscal subsidies from the Chinese central government than other provinces, other things being equal.

Politburo membership for provincial officials should be positively correlated with provincial budgetary revenue remittances to the central government and not related to central fiscal assistance to the provinces. We expect a positive sign for the coefficient of the independent variable when Remittance is the dependent variable, and no significant relationship between the independent variable and Subsidy in empirical estimations.

\section{Empirical analysis}

\subsection{Model specifications and estimation issues}

Due to the 'level' data of the dependent variable with possible unit root problems and the time-series cross-section nature of the dataset, I use a panel error correction model that regresses the firstdifferenced dependent variable on both the lagged and the first-differenced independent variable, as well as a lagged dependent variable (De Boef and Keele, 2008). ${ }^{15}$ An error correction model is also attractive as it lends itself easily to the testing of both the long-term and short-term effects of slowly-changing independent variables (Beck and Katz, 2011) such as ours - Politburo membership for provincial officials. The empirical model assumes the following form:

$$
\begin{aligned}
\Delta \text { Fiscal Flows }_{i, t}= & \beta_{0} \text { Politburo }_{i, t-1}+\beta_{1} \Delta \text { Politburo }_{i, t}+\beta_{2} \text { Fiscal Flows }_{i, t-1} \\
& +\beta_{3} \text { Control Variables }_{i, t-1}+\beta_{4} \Delta \text { Control Variables }_{i, t}+\alpha_{i}+\lambda_{t}+\varepsilon_{i, t}
\end{aligned}
$$

Please note that I estimate two dependent variables - Remittance and Subsidy - separately. In Equation (1), therefore, $\Delta$ Fiscal Flows $s_{i, t}$ is the first-differenced dependent variable for province $i$ during year $t$, denoting the annual first-difference changes in provincial per capita remittances to the central government $\left(\Delta\right.$ Remittance $\left._{i, t}\right)$ and in central fiscal subsidies to the provinces $\left(\Delta\right.$ Subsidy $\left._{i, t}\right)$, respectively. Politburo $_{i, t-1}$ and $\Delta$ Politburo $_{i, t}$ are the lagged (by 1 year) and first-differenced independent variable, with $\beta_{0}$ and $\beta_{1}$ as their respective coefficient vectors. Fiscal Flows $s_{i, t-1}$ is the lagged dependent variable Remittance $_{i, t-1}$ and Subsidy ${ }_{i, t-1}$ - respectively, with a coefficient vector of $\beta_{2}$.

Many other provincial-level factors could also affect central-provincial fiscal flows and need to be controlled for during estimation. I include exposure to the global markets (Exports, the percentage share of exports in provincial GDP), wealth (Per Capita GDP, the natural log of provincial per capita GDP at constant $1977 \mathrm{RMB}$ ), population size (Population, the percentage share of provincial population in national total), existing fiscal health (Surplus, the difference between per capita local budgetary revenues and per capita budgetary spending at constant 1977 RMB), and urbanization (Urbanization,

\footnotetext{
Chongqing through a worldwide recession and increased central government stimulus spending in China, the average remittance from Chongqing was about 18 RMB during 2008-2011, compared with an average of 16.2 RMB during 1997-2007. Fiscal data for Chongqing and Shanghai are from Zhongguo Caizheng Nianjian Bianji Weiyuanhui (2005, 2007-2012); data on population and price indices used to calculate the real per capita remittance are from http://www.cqtj.gov.cn/tjnj/ 2012/indexch.htm, and http://jj.sh.gov.cn/html/sjfb/201701/1000198.html, respectively, accessed on 10 October 2017.

${ }^{15}$ For the remittance data, panel unit root tests with automatic lag selection, assuming either individual or common unit root process, generally reject the null hypothesis of unit root when an individual panel intercept or both an individual intercept and trend are included. For the subsidy data, however, unit root tests cannot reject the null of unit root when 'level' data are used. For Beck and Katz (2011), due to the relatively short time-series in most data used in comparative political economy research, results of panel unit root tests might not be robust to the possible lengthening of the time series into the future time periods. De Boef and Keele (2008) thus suggest that a general error correction model is preferable even if unit root problems are not a concern.
} 
the percentage share of urban employment in total provincial employment). ${ }^{16}$ I want to control for whether the more export-oriented, richer, larger, fiscally healthier, and more urbanized provinces were subject to different fiscal extraction or compensation by the central government.

Building on the scholarship on factionalism in Chinese elite politics, Shih (2008) argues that provincial officials boasting close personal ties to the head of the CCP or Deng Xiaoping (until his death in 1997) received more favorable bank loan polices from the central government during this era. Such ties might also help the provinces reduce their fiscal burdens and increase central fiscal inflows. To explore this possibility, I add a dummy variable (Connections), with an expected negative sign for the coefficient for the analysis of remittances and a positive sign for the subsidy estimations. ${ }^{17}$ I also follow Zheng et al. (2013) to add a spatial lag of the dependent variable (Neighbors), calculated as the average remittances or subsidies for all provinces bordering province $i$ in year $t,{ }^{18}$ to account for possible spillover effects. These seven variables are grouped under the matrix Control Variables; they are included in all the models. $\beta_{3}$ and $\beta_{4}$ are the coefficient vectors for their lagged and firstdifferenced values, respectively. I summarize the variables in Table 1.

In the robustness specifications, I also control for the role of a couple more sample-specific variables that I will introduce as I discuss the results. To capture the unobservable province-specific and year-specific 'fixed' effects (Green et al., 2001), I include a full set of province and year dummy variables, denoted as $\alpha_{i}$ and $\lambda_{t}$, respectively, in Equation (1). Finally, $\varepsilon_{i, t}$ is an error term. I use ordinary least squares (OLS) regressions with robust standard errors. ${ }^{19}$

\subsection{Empirical results}

\subsubsection{Provincial remittances to the center}

I present the empirical results for provincial remittances and central subsidies in Tables 2 and 3 separately. Model 1 in Table 2 presents the baseline result on remittances. It explains over 59\% of the overall variance in changes in provincial per capita remittances to the central government, a remarkable fit given the use of the 'first-differenced' values of the dependent variable. Consistent with $\mathrm{Hb}$, both the lagged and first-differenced values of Politburo are positively and significantly associated with the first-differenced Remittance. This suggests that the independent variable exerts positive shortterm and long-term effects on the dependent variable. Please note the average provincial population size in this period was about 40 million and the average annual total gross remittances for all provinces combined was about 544 million RMB (1977 constant value). ${ }^{20}$ The short-term effect is captured by the coefficient of $\Delta$ Politburo $_{i, t}$ in Model 1 (about 1.54). In the short term, other things being equal, sending a Politburo member to lead a province is associated with an immediate increase of about 61.6 (i.e., $40 \times 1.54)$ million RMB (1977 constant value) of provincial remittances to the central government, or over $11 \%$ of the average annual total.

To estimate the long-term effect, I first compute the long-run multiplier (LRM) by dividing the coefficient of the lagged independent variable over the negative value of the coefficient of the lagged dependent variable (Kaufman and Segura-Ubiergo, 2001; De Boef and Keele, 2008). I obtain a value of

\footnotetext{
${ }^{16}$ Provincial general retail price indices are used as GDP deflators. Data on price indices and other provincial-level economic variables (unless noted otherwise) are from Guojia Tongji Ju (1999, 2000-2005, 2005). Provincial export data are from Duiwai Jingji Maoyibu (1987-2003) for 1994-2002, and Shangwubu (2004-2005) for 2003-2004. Because export data are in U.S. dollars and GDP data are in RMB, I use the average annual exchange rate (the middle rate) to calculate provincial exports/GDP share. Exchange rate data are from Guojia Tongji Ju (2005).

${ }^{17}$ It takes on a value of 1 if the provincial party secretary enjoyed 'birth, work, or educational ties' with the CCP General Secretary or Deng Xiaoping or if the province was the latter's birth province (Shih 2008: 67-68). I thank Victor Shih for sharing his data.

${ }^{18} \mathrm{An}$ island province, Hainan does not have contiguous land-based neighbors. I use Guangdong as a neighboring province for Hainan which was part of Guangdong province before becoming a separate provincial unit in 1988

${ }^{19}$ I have found that robust standard errors tend to be more conservative than panel corrected standard errors that correct for panel heteroskedasticity and spatial correlation (Beck and Katz 1995). I thus report the robust standard errors here.

${ }^{20}$ The average annual remittance for all provinces combined was 2.2 billion RMB (current value) in this period.
} 
Table 1. Summary statistics for variables used

\begin{tabular}{|c|c|c|c|c|c|c|}
\hline Variable & Definitions & Obs. & Mean & Std. dev. & Min & Max \\
\hline$\Delta$ Remittance & Provincial real per capita remittances & 270 & -0.143 & 3.782 & -30.621 & 17.987 \\
\hline Remittance & to the central government (1977 RMB) & 270 & 18.877 & 38.613 & 0 & 235.905 \\
\hline$\Delta$ Subsidy & Provincial real per capita subsidies from & 270 & 19.313 & 37.035 & -71.839 & 320.819 \\
\hline Subsidy & the central government (1977 RMB) & 270 & 88.033 & 138.051 & 1.561 & 1194.807 \\
\hline Politburo & Dummy variable on Politburo membership & 270 & 0.152 & 0.360 & 0 & 1 \\
\hline$\Delta$ Politburo & for provincial party secretary & 270 & 0.011 & 0.220 & -1 & 1 \\
\hline Neighbors (Remittance) & Average provincial real per capita remittances & 270 & 14.931 & 18.300 & 0.013 & 75.756 \\
\hline $\begin{array}{l}\Delta \text { Neighbors } \\
\quad(\text { Remittance) }\end{array}$ & of neighboring provinces (1977 RMB) & 270 & -0.144 & 2.503 & -15.418 & 9.291 \\
\hline Neighbors (Subsidy) & Average provincial real per capita subsidies of & 270 & 83.741 & 90.618 & 1.561 & 586.413 \\
\hline$\Delta$ Neighbors (Subsidy) & neighboring provinces (1977 RMB) & 270 & 19.308 & 24.976 & -32.829 & 178.647 \\
\hline Exports & Provincial exports/GDP (\%) & 270 & 13.546 & 15.958 & 2.045 & 92.903 \\
\hline$\Delta$ Exports & & 270 & 0.261 & 2.431 & -7.211 & 10.286 \\
\hline Connections & iable on presence of $\mathrm{cc}$ & 270 & 0.385 & 0.488 & 0 & 1 \\
\hline$\Delta$ Connections & for provincial party secretaries & 270 & 0.011 & 0.339 & -1 & 1 \\
\hline Per Capita GDP & Per capita GDP (logged) (1977 RMB) & 270 & 7.442 & 0.560 & 6.185 & 9.082 \\
\hline$\triangle$ Per Capita GDP & & 270 & 0.104 & 0.033 & -0.001 & 0.219 \\
\hline Population & Provincial share of national population (\%) & 270 & 3.227 & 2.108 & 0.194 & 9.216 \\
\hline$\Delta$ Population & & 270 & -0.011 & 0.153 & -2.497 & 0.127 \\
\hline Surplus & Provincial real per capita budgetary surplus & 270 & -122.305 & 140.482 & -1267.741 & 15.325 \\
\hline$\Delta$ Surplus & (1977 RMB) & 270 & -21.730 & 42.580 & -405.270 & 154.400 \\
\hline Urbanization & Share of urban employment in provincial & 270 & 32.332 & 15.382 & 13.884 & 76.051 \\
\hline$\Delta$ Urbanization & employment (\%) & 270 & 0.077 & 1.802 & -10.736 & 8.616 \\
\hline Politburo Share & Provincial share of Politburo membership (\%) & 270 & 0.580 & 1.559 & 0 & 7.113 \\
\hline$\Delta$ Politburo Share & & 270 & 0.031 & 0.629 & -4.415 & 4.545 \\
\hline Alternate CC & embership & 270 & 0.063 & 0.243 & 0 & 1 \\
\hline$\triangle$ Alternate $C C$ & cretary in the CC & 270 & 0.033 & 0.199 & -1 & 1 \\
\hline Non-CC & Dummy variable on non-membership & 270 & 0.011 & 0.105 & 0 & 1 \\
\hline$\Delta$ Non-CC & of provincial party secretary in the CC & 270 & -0.004 & 0.061 & -1 & 0 \\
\hline
\end{tabular}

Note: The summary only includes variables used in analysis reported in Tables 2 and 3. All 'level' variables are lagged by one year.

around 3.8 (i.e.,2.79/ - [ - 0.73]), with an estimated standard error of 1.75, suggesting that the LRM is also statistically significant (the $p$ value being about 0.031 ) ${ }^{21}$ Over the sample period, all else being equal, posting a Politburo member in a province is associated with an increase of over 152 (i.e., $3.8 \times 40$ ) million RMB of remittances to the center. Meanwhile, the positive and significant effects of the independent variable are also quite robust.

Model 2 drops all the observations from Shanghai, the largest fiscal contributor in this period to see whether the results are driven by a possible outlier. ${ }^{22}$ In Model 3, I replace the dummy variable with a more precise measure of annual provincial percentage share of Politburo membership as our main independent variable (Sheng, 2005). As we can see, the results concerning provincial presence at the CCP Politburo are broadly consistent with those of Model 1.

Meanwhile, Kung and Chen (2011) suggest that a major culprit of the great Chinese famine in the 1960s was the over-eagerness of provincial party secretaries who were alternate members of the CCP Central Committee to embrace the policy radicalism of the country's supreme leader Mao Zedong in grain production. One possible reason is that as members of the lowest-ranking CC category, these officials were more likely to be rewarded with further career advancement for policy compliance than other provincial party secretaries who might have already exhausted their promotion potential. To control for the role of these provincial leaders during the post-Mao era, in Model 4 I add two dummy variables. Alternate $C C$ takes on a value of 1 if the provincial party secretary of a province in a year was an alternate CC member, and Non-CC equals 1 if the provincial party secretary was

\footnotetext{
${ }^{21}$ The formula for estimating the variance of the LMR is from De Boef and Keele (2008: 191-192). The degree of freedom is 207 .

${ }^{22}$ Because Urbanization data are not published for Shanghai for 2002-2005, only six observations from Shanghai are included in the full sample in Model 1 and are now dropped from Model 2.
} 
Table 2. Provincial Politburo representation and fiscal extraction

\begin{tabular}{|c|c|c|c|c|c|c|c|c|c|c|}
\hline & \multicolumn{2}{|c|}{ Model 1} & \multicolumn{2}{|c|}{ Model 2} & \multicolumn{2}{|c|}{ Model 3} & \multicolumn{2}{|c|}{ Model 4} & \multicolumn{2}{|c|}{ Model 5} \\
\hline & Coefficient & S.E. & Coefficient & S.E. & Coefficient & S.E. & Coefficient & S.E. & Coefficient & S.E. \\
\hline Politburo & $2.791^{\star \star}$ & $(1.274)$ & $2.856^{\star \star}$ & $(1.275)$ & & & $2.840^{\star \star}$ & $(1.277)$ & $3.137^{\star \star}$ & $(1.382)$ \\
\hline$\Delta$ Politburo & $1.536^{\star \star}$ & $(0.757)$ & $1.440^{\star}$ & $(0.751)$ & & & $1.608^{\star \star}$ & $(0.776)$ & $1.484^{\star}$ & $(0.819)$ \\
\hline Politburo Share & & & & & $0.593^{\star \star}$ & $(0.278)$ & & & & \\
\hline$\Delta$ Politburo Share & & & & & $0.999^{\star}$ & $(0.548)$ & & & & \\
\hline Alternate CC & & & & & & & 0.574 & $(0.563)$ & & \\
\hline$\triangle$ Alternate $C C$ & & & & & & & -0.469 & $(0.371)$ & & \\
\hline Non-CC & & & & & & & $3.050^{\star \star \star}$ & $(0.971)$ & & \\
\hline$\Delta$ Non-CC & & & & & & & $2.030^{\star \star \star}$ & $(0.726)$ & & \\
\hline Neighbors & -0.032 & $(0.136)$ & -0.130 & $(0.133)$ & -0.001 & $(0.132)$ & -0.041 & $(0.139)$ & -0.142 & $(0.143)$ \\
\hline$\Delta$ Neighbors & -0.016 & $(0.143)$ & -0.077 & $(0.141)$ & 0.026 & $(0.143)$ & -0.034 & $(0.147)$ & -0.117 & $(0.148)$ \\
\hline Exports & -0.004 & $(0.081)$ & 0.018 & $(0.080)$ & 0.008 & $(0.079)$ & -0.019 & $(0.083)$ & 0.016 & $(0.076)$ \\
\hline$\Delta$ Exports & -0.025 & $(0.105)$ & -0.103 & $(0.098)$ & 0.000 & $(0.097)$ & -0.038 & $(0.107)$ & -0.041 & $(0.102)$ \\
\hline Connections & 0.348 & $(0.500)$ & 0.181 & $(0.504)$ & 0.398 & $(0.491)$ & 0.309 & $(0.513)$ & 0.431 & $(0.522)$ \\
\hline$\Delta$ Connections & -0.422 & $(0.680)$ & -0.600 & $(0.664)$ & -0.329 & $(0.621)$ & -0.400 & $(0.687)$ & -0.115 & $(0.565)$ \\
\hline Per Capita GDP & $25.538^{\star \star \star}$ & $(5.966)$ & $24.476^{\star \star \star}$ & $(5.753)$ & $25.362^{\star \star \star}$ & $(5.920)$ & $25.881^{\star \star \star}$ & (6.129) & $30.520^{\star \star \star}$ & $(6.594)$ \\
\hline$\triangle$ Per Capita GDP & $15.819^{\star}$ & $(8.335)$ & $18.091^{\star \star}$ & (8.065) & $15.336^{\star}$ & $(8.104)$ & $17.557^{\star \star}$ & $(8.687)$ & $19.156^{\star \star}$ & $(8.937)$ \\
\hline Population & 0.610 & $(0.646)$ & 0.754 & $(0.656)$ & 0.448 & $(0.669)$ & 0.680 & $(0.648)$ & 0.928 & $(0.621)$ \\
\hline$\Delta$ Population & 0.365 & $(0.499)$ & 0.484 & $(0.500)$ & 0.384 & $(0.523)$ & 0.341 & $(0.493)$ & 0.602 & $(0.482)$ \\
\hline Surplus & $0.008^{\star \star \star}$ & $(0.003)$ & $0.009^{\star * *}$ & $(0.003)$ & $0.008^{\star \star \star}$ & $(0.003)$ & $0.008^{\star \star \star}$ & $(0.003)$ & -0.011 & $(0.009)$ \\
\hline$\Delta$ Surplus & 0.004 & $(0.003)$ & 0.005 & $(0.003)$ & 0.004 & $(0.003)$ & 0.004 & $(0.004)$ & -0.009 & $(0.007)$ \\
\hline Urbanization & -0.039 & $(0.091)$ & $-0.173^{\star \star}$ & $(0.086)$ & -0.021 & $(0.088)$ & -0.033 & $(0.091)$ & -0.082 & $(0.101)$ \\
\hline$\Delta$ Urbanization & -0.044 & $(0.129)$ & $-0.206^{\star}$ & $(0.110)$ & -0.043 & $(0.126)$ & -0.041 & $(0.128)$ & -0.101 & $(0.150)$ \\
\hline Remittance & $-0.733^{\star \star \star}$ & $(0.127)$ & $-0.783^{\star \star \star}$ & $(0.130)$ & $-0.732^{\star \star \star}$ & (0.135) & $-0.724^{\star \star \star}$ & $(0.126)$ & $-0.810^{\star \star \star}$ & $(0.132)$ \\
\hline Constant & -53.635 & $(45.141)$ & $-129.561^{\star \star \star}$ & $(41.220)$ & -54.866 & $(45.670)$ & -62.852 & $(47.167)$ & $-84.599^{\star}$ & (48.373) \\
\hline Observations & 270 & & 264 & & 270 & & 270 & & 226 & \\
\hline Adjusted $R^{2}$ & 0.593 & & 0.617 & & 0.603 & & 0.591 & & 0.646 & \\
\hline
\end{tabular}

Note: The dependent variable is $\Delta$ Remittance, the annual first difference in provincial per capita budgetary remittances to the central government (1977 RMB) during $1996-2004$, and estimated with an error

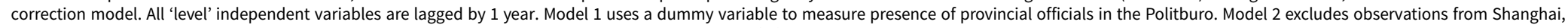

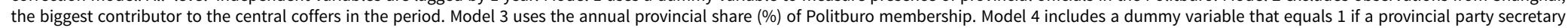

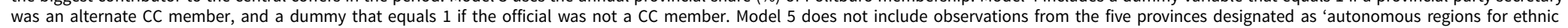
minorities.' All estimations include a full set of province and year dummy variables whose results are omitted. Robust standard errors are reported in parentheses.

${ }^{\star \star \star} P<0.01 ;{ }^{\star \star} P<0.05 ;{ }^{\star} P<0.1$ (two-tailed tests). 
Table 3. Provincial Politburo representation and central fiscal compensation

\begin{tabular}{|c|c|c|c|c|c|c|c|c|c|c|}
\hline & \multicolumn{2}{|c|}{ Model 1} & \multicolumn{2}{|c|}{ Model 2} & \multicolumn{2}{|c|}{ Model 3} & \multicolumn{2}{|c|}{ Model 4} & \multicolumn{2}{|c|}{ Model 5} \\
\hline & Coefficient & S.E. & Coefficient & S.E. & Coefficient & S.E. & Coefficient & S.E. & Coefficient & S.E. \\
\hline Politburo & -6.427 & $(8.137)$ & -6.926 & (6.498) & & & -6.655 & (8.038) & -1.554 & $(5.885)$ \\
\hline$\Delta$ Politburo & $-10.976^{\star}$ & $(6.596)$ & -8.021 & (5.039) & & & -8.278 & $(6.724)$ & 0.192 & $(4.413)$ \\
\hline Politburo Share & & & & & 0.148 & $(2.028)$ & & & & \\
\hline$\Delta$ Politburo Share & & & & & -1.724 & $(2.457)$ & & & & \\
\hline Alternate CC & & & & & & & $13.581^{\star}$ & $(7.266)$ & & \\
\hline$\Delta$ Alternate CC & & & & & & & 8.872 & (8.704) & & \\
\hline Non-CC & & & & & & & 4.410 & $(7.451)$ & & \\
\hline$\Delta$ Non-CC & & & & & & & 7.057 & $(4.346)$ & & \\
\hline Neighbors & 0.067 & $(0.050)$ & $0.100^{*}$ & $(0.056)$ & 0.060 & $(0.050)$ & $0.088^{*}$ & $(0.051)$ & $0.137^{\star \star}$ & $(0.063)$ \\
\hline$\Delta$ Neighbors & $0.322^{\star \star}$ & $(0.142)$ & $0.314^{\star \star}$ & $(0.134)$ & $0.326^{\star \star}$ & $(0.143)$ & $0.364^{\star \star}$ & $(0.150)$ & $0.403^{\star \star}$ & $(0.191)$ \\
\hline Exports & -1.071 & $(0.657)$ & -0.630 & $(0.529)$ & $-1.137^{\star}$ & $(0.650)$ & $-1.152^{\star}$ & $(0.683)$ & -0.820 & $(0.511)$ \\
\hline$\Delta$ Exports & -0.974 & $(0.785)$ & -0.553 & $(0.661)$ & -1.046 & $(0.798)$ & -0.932 & $(0.770)$ & -0.024 & $(0.630)$ \\
\hline Connections & 5.052 & $(4.476)$ & 2.322 & $(3.817)$ & 4.970 & $(4.434)$ & 3.078 & $(4.521)$ & 3.894 & $(3.838)$ \\
\hline$\Delta$ Connections & 6.156 & (4.633) & 1.061 & $(3.250)$ & 6.235 & (4.615) & 4.389 & (4.518) & 3.947 & $(2.694)$ \\
\hline Per Capita GDP & 2.802 & $(46.220)$ & -60.749 & $(39.850)$ & 3.654 & $(46.467)$ & 2.047 & $(48.230)$ & -41.770 & $(38.768)$ \\
\hline$\triangle$ Per Capita GDP & 60.884 & (79.599) & 0.581 & (58.054) & 69.840 & $(78.836)$ & 70.997 & $(82.523)$ & 67.400 & (56.564) \\
\hline Population & 3.045 & $(2.896)$ & 4.985 & $(3.410)$ & 3.250 & $(2.907)$ & $5.146^{\star}$ & $(3.044)$ & $7.132^{\star}$ & (3.840) \\
\hline$\Delta$ Population & -1.522 & $(2.491)$ & -2.238 & $(2.901)$ & -1.779 & (2.398) & -1.737 & $(2.440)$ & -2.372 & $(2.476)$ \\
\hline Surplus & $-0.564^{\star \star}$ & $(0.224)$ & $-0.455^{\star \star \star}$ & $(0.162)$ & $-0.556^{\star \star}$ & $(0.224)$ & $-0.553^{\star \star}$ & $(0.216)$ & $-0.390^{\star \star \star}$ & $(0.140)$ \\
\hline$\Delta$ Surplus & $-0.577^{\star \star \star}$ & $(0.124)$ & $-0.275^{\star \star}$ & $(0.121)$ & $-0.574^{\star \star \star}$ & $(0.124)$ & $-0.561^{\star \star \star}$ & $(0.123)$ & -0.150 & $(0.101)$ \\
\hline Urbanization & -0.379 & $(0.937)$ & -0.822 & $(0.764)$ & -0.382 & $(0.929)$ & -0.293 & $(0.929)$ & -0.892 & $(0.725)$ \\
\hline$\Delta$ Urbanization & -0.737 & $(0.662)$ & -0.585 & $(0.557)$ & -0.660 & $(0.663)$ & -0.802 & $(0.667)$ & -0.717 & $(0.600)$ \\
\hline Subsidy & $-0.598^{\star \star \star}$ & $(0.219)$ & $-0.596^{\star \star \star}$ & $(0.168)$ & $-0.589^{\star \star \star *}$ & $(0.218)$ & $-0.591^{\star \star \star}$ & $(0.213)$ & $-0.573^{\star \star \star}$ & $(0.155)$ \\
\hline Constant & -21.930 & $(419.002)$ & 523.234 & (332.875) & -46.349 & (402.105) & -19.407 & $(454.549)$ & 370.853 & (307.465) \\
\hline Observations & 270 & & 261 & & 270 & & 270 & & 226 & \\
\hline Adjusted $R^{2}$ & 0.651 & & 0.545 & & 0.649 & & 0.651 & & 0.544 & \\
\hline
\end{tabular}

Note: The dependent variable is $\Delta$ Subsidy, the annual first difference in central fiscal subsidies (1977 RMB) to each province during 1996-2004, and estimated with an error correction model. All 'level' independent

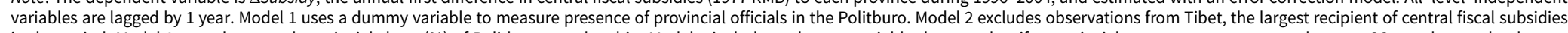

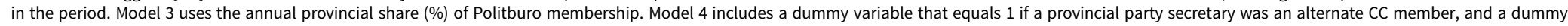

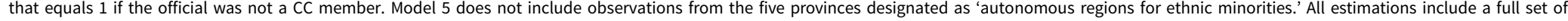
province and year dummy variables whose results are omitted. Robust standard errors are reported in parentheses.

${ }^{\star \star \star} P<0.01 ;{ }^{* \star} P<0.05 ;{ }^{\star} P<0.1$ (two-tailed tests). 
neither a full nor an alternate CC member. Contrary to the findings for the pre-reform years by Kung and Chen (2011), provincial party secretaries who were alternate CC members did not seem to have overseen larger remittances to the central government than those who were full CC members but not Politburo members (the omitted category). Instead, provinces led by party chiefs who were not CC members of any type (not an alternate or full CC member or a Politburo member) tended to remit more budgetary revenues than those led by the non-Politburo full CC members. These officials could have harbored the greatest incentives to implement central fiscal extraction in their jurisdictions in order to strive for accession to CC membership. Nevertheless, the results for the main independent variable remain largely unchanged.

Finally, in Model 5, I exclude observations from five provincial units that are 'autonomous regions for ethnic minorities' - Tibet, Xinjiang, Ningxia, Guangxi, and Inner Mongolia because other scholars have suggested that these regions might be subject to a different logic of fiscal extraction and compensation due to the need to appease ethnic minorities by the central government (Lü and Landry, 2014). Again, in both Models 4 and 5, the coefficients for the lagged and first-differenced Politburo remain positive and significant.

Among the control variables, Per Capita GDP is the most robust predictor of provincial revenue remittance. Both the lagged and first-differenced variable are positively and significantly correlated with the first-differenced Remittance across all models in Table 2. The positive effects of provincial wealth on provincial fiscal contributions to the center, in both the long term and short term, imply the highly redistributive nature of central fiscal extraction in China during this period. It is also interesting to note that positive long-term effect of local fiscal health captured by the lagged Surplus variable. However, its coefficient turns negative and is no longer significant at the conventional levels for Model 5 excluding the ethnic minority regions.

Less certain are the results for other variables. Consistent with Shih (2008), the coefficient of the first-differenced Connections is negative. In the short term, provinces led by officials boasting close personal ties to powerful national patrons might subsequently witness a drop in provincial fiscal contributions to the center. Still, its coefficient is not statistically significant at the conventional levels in any of the models. ${ }^{23}$ The coefficient for Neighbors, the spatial lag capturing the possible effect of interprovincial competition also fails to achieve statistical significance at the conventional levels. The same can be largely said for the other variables.

\subsubsection{Central fiscal subsidies for the provinces}

In Table 3, I report the results on the analysis of central fiscal subsidies in this period to examine whether Politburo members managed to haul larger central fiscal pork into the provinces under their watch. The specifications mirror those of Table 2 for easier comparison with the remittance models. ${ }^{24}$ In Model 1, I include the full sample. In Model 2, I exclude observations from Tibet, the largest recipient of central fiscal largesse during these years, as noted above. In Model 3, I use an alternative measure of the independent variable that is based on the percentage share of provincial officials in the Politburo. Model 4 controls for the role of provincial party secretaries who were either alternate CC members or not members of any type in the Central Committee at all. In Model 5, I exclude all observations from provinces that are ethnic minority regions.

Consistent with the findings for the year of 1998 by Wang (2004: 232-234) and for the period of 1999-2009 by Fan and Zhang (2011), but contrary to the implications of $\mathrm{Ha}$, provincial presence at

\footnotetext{
${ }^{23}$ Using data that code Connections on the sole basis of shared work experiences, a dummy variable that equals 1 if a provincial party secretary had ever previously worked in the same unit and at the same administrative level (although not necessarily of equal rank) for over half a year with Deng Xiaoping for my data covering 1994-1996, with Jiang Zemin for 1994-2002, with Hu Jintao for 2003-2004, and 0 otherwise, does not change the results for either dependent variable.

${ }^{24}$ In additional analysis not reported but available upon request, I also control for the role of provincial dependency ratio (defined as the ratio of the percentage share of population of age $0-14$ over the percentage share of population of age 15-64 plus the ratio of the percentage share of population of over age 65 over the percentage share of population of age 15-64). The results for the other variables remain largely unchanged.
} 
the Politburo did not seem to be associated with greater inflows of central fiscal subsidies for the provinces in any of the models. In fact, the coefficients for the lagged and first-differenced Politburo are negative in all but Model 5 where the coefficient for the first-differenced Politburo is positive. Still, caution is in order as only the coefficient for the first-differenced Politburo in Model 1 is marginally significant (at 0.1). This suggests while provincial presence at the CCP Politburo seemed to have eased central revenue extraction from the provinces, it did not appear to have facilitated inflows of central fiscal subsidies for the provinces.

By contrast, the positive and weakly significant effects of the lagged Alternate CC $(p=0.063)$ and first differenced Non-CC $(p=0.106)$ in Model 4 suggest that provincial party secretaries who rank near the bottom of the CCP elite totem pole tended to do a better job in bringing in central fiscal money than their counterparts who were either Politburo members or full CC members. It is also interesting to note the positive effect of the spatial lag variable, Neighbors, the average value of the dependent variable for all bordering provinces. Although the coefficient for its lagged value is only significant in Models 2, 4, and 5, the coefficient for the first-differenced variable is all positive and highly significant (at 0.05). This suggests some short-term contagion effect of fiscal subsidies in that central fiscal subsidies tended to flow to those provinces whose neighbors also received more.

The results here also suggest that central fiscal subsidies in China have been highly responsive to the fiscal needs of the provinces as the coefficients for both the lagged and first-differenced Surplus, real provincial per capita budgetary surplus, are all negative and for the most part highly significant (except for the first-differenced Surplus in Model 5). Provinces with both short-term and long-term deficits would receive greater central fiscal assistance, suggesting the highly redistributive nature of central fiscal compensation even in a period in China not well known for substantial regional redistribution. The results for other variables, however, are either sensitive to sample coverage or generally not significant. The negative coefficients of Exports suggest that fiscal assistance tended to favor provinces doing less well in the international markets, but the coefficient for the lagged Exports is only slightly significant in Models 3 and 4. Likewise, the positive coefficient for lagged Population is only significant in Models 4 and 5. The coefficients for Connections, Per Capita GDP, and Urbanization, however, are generally not significant, suggesting little evidence that poorer provinces, those led by provincial party chiefs better connected with the national leaders, or more urbanized provinces tended to receive more central fiscal assistance during this period.

\subsection{Discussion}

\subsubsection{Selection bias}

I have presented robust evidence that Politburo membership for provincial officials was positively correlated with provincial budgetary remittances to the central government in the aftermath of the 1994 fiscal reform. One concern is possible selection bias. In the analysis of the determinants of provincial revenue remittances to the central government, I have included provincial-level variables such as $P e r$ Capita GDP, Urbanization, Population, and Exports shown to be significant predictors of CCP Politburo membership for provincial leaders in this period (Sheng, 2009). However, we might not be sure whether I have controlled for every possible provincial-level factor affecting the assignment of Politburo members to the provinces. If any unobservable factors that influence both whether a province was ruled by a Politburo member and the amount of revenues a province was able to remit to the center are not included in the model estimating the effect of Politburo membership for provincial leaders on provincial fiscal remittance, the results might suffer from selection bias.

One way to correct this possible bias is Heckman's (1979) two-step selection model which requires the use of 'level' data. ${ }^{25}$ To estimate the selection-corrected effect of Politburo membership for

\footnotetext{
${ }^{25}$ Here I follow applications of a similar method used in Cheibub (1998) and Gandhi (2008). As noted, unit root is less of a problem for the Remittance data than for the Subsidy data according to panel unit root tests. I thank José Cheibub and Ruixue Jia for helpful discussions on the implementation of the Heckman analysis reported here.
} 
provincial officials on provincial revenue contributions, I first run a probit model, using a dummy variable indicating whether a province was ruled by a CCP Politburo member as the dependent variable. The independent variables include Exports, Per Capita GDP, Population, and Urbanization, as in Table 2. I also add GDP Grow (annual provincial GDP growth rates, in percentage), and two nonvarying dummy variables as well as a full set of year dummy variables, as in Sheng (2009). CAM indicates whether a province was a centrally administered municipality - for Beijing, Chongqing (since 1997), Shanghai, and Tianjin; Minority denotes whether a province was an ethnic minority region - Tibet, Xinjiang, Guangxi, Inner Mongolia, and Ningxia.

Meanwhile, the lambda (the inverse mills ratio) is the hazard rate generated in the first stage of the Heckman test. It measures the hypothetical possibility that a province, which is observed to be ruled by a Politburo member (or a non-Politburo member) in a year in the data, could have been led by an official who was not a Politburo member (or a Politburo member) in the same year. It can serve as a proxy of those unobserved factors that might influence both whether a province was led by a CCP Politburo member, and the revenues a province remitted to the central government. Using the same specification as Model 1 of Table 2 but only including the lagged 'level' variables, I now estimate separate OLS regressions for provinces/years under the rule of Politburo members and those under non-Politburo members. While the key independent variable Politburo is dropped from these regressions, lambda is included as an independent variable to obtain unbiased estimates of the other determinants of provincial remittances to the center. The results are presented in Table 4.

The unbiased coefficient estimates from these two separate regressions are then used to generate, for the entire sample of 273 observations, predicted values of provincial remittances under two scenarios. This counterfactual exercise enables us to compare, for each observation (a province in a year) from all provinces in all years covered in the sample under otherwise identical conditions, the predicted amount of provincial remittances to the center if they had been ruled by a Politburo member, and if they had been ruled by a non-Politburo member, respectively. The average values of these predictions based on the entire sample, together with their standard errors, are reported in the bottom row of Table 4. As we can see, corrected for selection, the average per capita remittances to the center if all provinces had been led by Politburo members is about 13.2 RMB while the average per capita remittances if all provinces had been ruled by non-Politburo leaders is only 6.1 RMB. The difference is 7.1 RMB, which is also highly statistically significant (at 0.01 ) in a difference of means test. While these efforts to address possible selection bias draw only on the 'level' data, the results are consistent with the error-correction analysis using both 'first-differenced' and 'level' data that suggest that CCP Politburo membership for provincial officials was associated with higher provincial budgetary remittances to the center.

\subsubsection{Reverse causality}

I also tackle the possibility of mutual causality between provincial Politburo membership and budgetary remittances. Previous research on the provincial-level determinants of provincial Politburo representation in the post-1978 era does not examine the role of preexisting provincial revenue remittances to the central government. Panel A in Table 5 presents analysis that broadly replicates Sheng's (2009) logistic regressions, but adds lagged Remittance as an independent variable. The dependent variable is a dummy variable on whether a province was led by a Politburo member in a year during 1996-2005. As in the Heckman test, I include Per Capita GDP, Urbanization, Population, Exports, GDP Grow, and two dummy variables CAM and Minority.

Models 1 and 2 use annual year dummy variables to correct for serial correlation (Beck et al., 1998); Models 3 and 4 replace the year dummies with a lagged dependent variable (Keele and Kelly, 2006). Models 1 and 3 include all observations. Models 2 and 4 leave out observations from Shanghai due to concerns about the 'Shanghai gang' logic. Politburo membership for officials from Shanghai might reflect efforts by Jiang Zemin to build a personal patron-client network, rather than the importance of other provincial-level factors included in estimation. 
Table 4. Provincial Politburo representation and fiscal extraction in China: Heckman selection analysis

\begin{tabular}{|c|c|c|c|c|}
\hline & \multicolumn{2}{|c|}{ Politburo } & \multicolumn{2}{|c|}{ Non-Politburo } \\
\hline & Coefficient & S.E. & Coefficient & S.E. \\
\hline Neighbors & -0.338 & $(0.566)$ & -0.036 & $(0.098)$ \\
\hline Export & 0.195 & $(0.308)$ & 0.044 & $(0.064)$ \\
\hline Connections & -0.310 & $(1.844)$ & 0.078 & $(0.468)$ \\
\hline Per Capita GDP & $62.936^{\star \star}$ & $(29.008)$ & $15.340^{\star \star \star}$ & $(3.716)$ \\
\hline Population & 2.237 & $(11.127)$ & $2.474^{\star \star}$ & $(1.008)$ \\
\hline Surplus & -0.019 & $(0.037)$ & $0.007^{\star \star \star}$ & $(0.002)$ \\
\hline Urbanization & 0.327 & $(0.301)$ & 0.113 & $(0.100)$ \\
\hline Remittance & -0.222 & $(0.232)$ & $0.169^{\star \star \star}$ & $(0.057)$ \\
\hline Lambda & -2.431 & $(6.803)$ & $2.722^{\star \star}$ & $(1.070)$ \\
\hline Constant & $-459.642^{\star}$ & $(231.328)$ & $-114.735^{\star \star \star}$ & $(26.128)$ \\
\hline Observations & 42 & & 231 & \\
\hline Adjusted $R^{2}$ & 0.999 & & 0.988 & \\
\hline$F$ & 1167.47 & & 437.99 & \\
\hline Probability $>F$ & 0.000 & & 0.000 & \\
\hline & Average Remittance & S.E. & Average Remittance & S.E. \\
\hline Counterfactuals & $13.172^{\star \star \star}$ & $(2.867)$ & $6.123^{\star \star \star}$ & $(1.475)$ \\
\hline
\end{tabular}

Note: The table reports results from second-stage Heckman selection analysis. All 'level' independent variables are lagged by 1 year. All estimations include a full set of province and year dummy variables whose results are omitted. Standard errors are in parentheses. ${ }^{\star \star \star} P<0.01 ;{ }^{\star \star} P<0.05 ;{ }^{\star} P<0.1$ (two-tailed tests).

Indeed, Remittance itself does not appear to be a positive predictor of provincial presence at the CCP Politburo while the results for the other variables are broadly similar to those of Sheng (2009). More fiscal contribution to the central government by itself does not seem to increase the chance that a province would be ruled by a Politburo member. The opposite seems true. In Models 2 and 4 excluding observations from Shanghai, the coefficient of Remittance even turns negative and is statistically significant (at 0.05 and 0.1 , respectively). This does not bear out suspicions of possible mutual causality in analysis reported in Table 2.

Still, could the CCP national leaders have sent Politburo members to rule those fiscally underperforming provinces? To explore this alternative possibility, I first create a Remittance Performance variable by using the residuals predicted from an OLS estimation regressing the 'level' value of Remittance on the lagged 'level' independent and dependent variables of Model 1 of Table 2, but without the Politburo dummy variable. This new variable essentially captures the difference between the actual provincial fiscal remittances and the underlying remittance potential of the provinces, net of the effect of any possible fiscal effort by provincial leaders who were Politburo members. A positive value of Remittance Performance indicates that a province was contributing above its potential; a negative value suggests provincial underperformance in this regard. I replace Remittance in Models 1-4 of Table 5 with Remittance Performance (lagged by one year) and report the results in Models $5-8 .^{26}$ If the CCP national leaders were interested in sending Politburo members to rule those provinces remitting less than its potential in order to ease fiscal extraction from these provinces, we should expect a negative sign for Remittance Performance.

The coefficient of Remittance Performance takes on mixed signs, but fails to achieve statistical significance at the conventional levels. Actual or potential fiscal remittances of the provinces did not seem to have mattered for where the Politburo members were posted in this period. Once appointed, however, Politburo members have ensured greater budgetary revenue remittances to the center. There is thus little empirical support for concerns of mutual causality in the results linking Politburo membership for provincial officials with greater provincial fiscal remittances.

\footnotetext{
${ }^{26}$ Due to inclusion of a lagged dependent variable in the OLS regression in order to obtain the predicted value of Remittance, about a year's worth of data (over 30 observations) are lost in the process. I am indebted to Chris Gelpi for helpful suggestions on how to test for this alternative possibility.
} 
https://doi.org/10.1017/S1468109919000069 Published online by Cambridge University Press

Table 5. Provincial-level determinants of provincial Politburo representation

\begin{tabular}{|c|c|c|c|c|c|c|c|c|}
\hline \multirow[b]{2}{*}{ Panel A } & \multicolumn{2}{|c|}{ Model 1} & \multicolumn{2}{|c|}{ Model 2} & \multicolumn{2}{|c|}{ Model 3} & \multicolumn{2}{|c|}{ Model 4} \\
\hline & Coefficient & S.E. & Coefficient & S.E. & Coefficient & S.E. & Coefficient & S.E. \\
\hline Remittance & 0.003 & $(0.007)$ & $-0.049^{\star \star}$ & $(0.020)$ & -0.003 & $(0.006)$ & $-0.029^{\star}$ & $(0.017)$ \\
\hline Exports & $0.058^{\star \star \star}$ & $(0.013)$ & $0.061^{\star \star \star}$ & $(0.016)$ & $0.025^{\star *}$ & $(0.011)$ & $0.030^{\star \star \star}$ & $(0.012)$ \\
\hline GDP Grow & -0.102 & $(0.107)$ & -0.127 & $(0.111)$ & -0.144 & $(0.093)$ & $-0.164^{\star}$ & (0.093) \\
\hline Per Capita GDP & 0.987 & (1.245) & $2.464^{\star}$ & (1.424) & 1.697 & (1.249) & $2.184^{\star}$ & (1.242) \\
\hline Population & $1.415^{\star \star \star}$ & $(0.317)$ & $1.358^{\star \star \star}$ & $(0.337)$ & $0.746^{\star \star \star}$ & $(0.286)$ & $0.749^{\star \star \star}$ & (0.275) \\
\hline Urbanization & $0.139^{\star \star \star}$ & $(0.039)$ & $0.150^{\star \star \star}$ & $(0.044)$ & $0.061^{\star}$ & $(0.035)$ & $0.071^{\star \star}$ & (0.036) \\
\hline CAM & $3.225^{\star \star \star}$ & $(0.943)$ & $4.718^{\star \star \star}$ & $(1.056)$ & $2.162^{\star \star}$ & $(0.968)$ & $3.047^{\star \star \star}$ & (1.077) \\
\hline Minority & $4.154^{\star \star \star}$ & (1.106) & $3.570^{\star \star \star}$ & (0.979) & $2.708^{\star \star}$ & $(1.047)$ & $2.388^{\star \star \star}$ & (0.917) \\
\hline Politburo $_{i, t-1}$ & & & & & $3.763^{\star \star \star}$ & $(0.625)$ & $3.585^{\star \star \star}$ & (0.632) \\
\hline Constant & $-21.066^{\star \star}$ & (9.842) & $-31.715^{\star \star \star}$ & (11.649) & $-20.504^{\star \star}$ & (8.531) & $-23.924^{\star \star \star}$ & (8.811) \\
\hline Year dummies & Yes & & Yes & & No & & No & \\
\hline Log pseudolikelihood & -54.420 & & -51.069 & & -40.755 & & -40.041 & \\
\hline Observations & 302 & & 295 & & 302 & & 295 & \\
\hline Pseudo $R^{2}$ & 0.599 & & 0.583 & & 0.699 & & 0.673 & \\
\hline Wald $\chi^{2}$ & 89.84 & & 75.64 & & 81.32 & & 61.68 & \\
\hline \multirow[t]{2}{*}{ Probability $>\chi^{2}$} & 0.000 & & 0.000 & & 0.000 & & 0.000 & \\
\hline & \multicolumn{2}{|c|}{ Model 5} & \multicolumn{2}{|c|}{ Model 6} & \multicolumn{2}{|c|}{ Model 7} & \multicolumn{2}{|c|}{ Model 8} \\
\hline Panel B & Coefficient & S.E. & Coefficient & S.E. & Coefficient & S.E. & Coefficient & S.E. \\
\hline Remittance Performance & 0.086 & $(0.068)$ & 0.108 & $(0.074)$ & -0.010 & $(0.065)$ & -0.003 & $(0.067)$ \\
\hline Exports & $0.050^{\star \star \star}$ & $(0.012)$ & $0.054^{\star \star \star}$ & $(0.013)$ & $0.025^{\star *}$ & $(0.011)$ & $0.025^{\star \star}$ & $(0.011)$ \\
\hline GDP Grow & -0.164 & $(0.148)$ & -0.178 & $(0.149)$ & -0.161 & $(0.101)$ & -0.160 & $(0.100)$ \\
\hline Per Capita GDP & 1.473 & (1.033) & 0.917 & $(1.175)$ & 1.469 & $(1.362)$ & 1.436 & (1.352) \\
\hline Population & $1.414^{\star \star \star}$ & $(0.331)$ & $1.431^{\star \star \star}$ & $(0.335)$ & $0.780^{\star \star \star}$ & $(0.303)$ & $0.777^{\star \star \star}$ & (0.298) \\
\hline Urbanization & $0.133^{\star \star \star}$ & $(0.039)$ & $0.142^{\star \star \star}$ & $(0.041)$ & $0.068^{\star}$ & $(0.037)$ & $0.068^{\star}$ & (0.036) \\
\hline CAM & $3.322^{\star \star \star}$ & (0.995) & $3.219^{\star \star \star}$ & (1.009) & $1.880^{\star \star}$ & $(0.887)$ & $1.801^{\star \star}$ & (0.888) \\
\hline Minority & $4.185^{\star \star \star}$ & $(1.117)$ & $3.948^{\star \star \star}$ & (1.081) & $2.720^{\star \star}$ & $(1.067)$ & $2.691^{\star \star}$ & (1.055) \\
\hline Politburo $_{i, t-1}$ & & & & & $3.577^{\star \star \star}$ & $(0.634)$ & $3.525^{\star \star \star}$ & $(0.638)$ \\
\hline Constant & $-23.545^{\star \star \star}$ & (7.931) & $-19.128^{\star \star}$ & (8.750) & $-18.841^{\star \star}$ & (8.967) & $-18.553^{\star \star}$ & (8.911) \\
\hline Year dummies & Yes & & Yes & & No & & No & \\
\hline Log pseudolikelihood & -50.52 & & -49.26 & & -39.281 & & -39.105 & \\
\hline Observations & 270 & & 264 & & 270 & & 264 & \\
\hline Pseudo $R^{2}$ & 0.595 & & 0.568 & & 0.685 & & 0.657 & \\
\hline Wald $\chi^{2}$ & 87.94 & & 81.60 & & 70.77 & & 66.50 & \\
\hline Probability $>\chi^{2}$ & 0.000 & & 0.000 & & 0.000 & & 0.000 & \\
\hline
\end{tabular}

Note: The dependent variable is Politburo, a dummy variable that equals 1 if any provincial official was a Politburo member for a province/year during 1996-2005. It is estimated with logistic regressions. Politburo $t-1$ is the dependent variable lagged by 1 year. All other independent variables are lagged by 1 year. Remittance Performance is the value of the residual predicted from an OLS regression with the 'level' value of Remittance as the dependent variable, as in Model 1 of Table2, but only including the lagged 'level' independent and dependent variables, again without the Politburo dummy variable. Models 2, 4, 6, and 8 exclude observations from Shanghai. Robust standard errors are in parentheses.

${ }_{* \star *} P<0.01 ;{ }^{*} *<<0.05 ;{ }^{*} P<0.1$ (two-tailed tests). 


\subsubsection{Economic performance and Politburo promotions}

A related but distinct concern is whether the results on the effect of Politburo membership on provincial fiscal remittances were driven by the possibility that, on the individual level, provincial leaders were more likely to be promoted to be Politburo members by overseeing faster economic growth, which in turn could increase provincial capacity for fiscal contribution to the center. ${ }^{27}$ Indeed, a 'performance-based authoritarianism' thesis has animated much of political economy scholarship on China. It attributes the country's remarkable reform-era economic success in part to merit-based political selection whereby the CCP has rewarded competent local leaders presiding over faster economic growth with greater career advancement. To tackle this possibility, I use annual individual-level data on the provincial party secretaries who were not yet Politburo members during this period and test the effect of an official's economic performance record on the probability of the official being promoted to Politburo membership. ${ }^{28}$

The dependent variable Promotion is a dummy variable equaling 1 if an official joined the Politburo in a year, and 0 otherwise. The main independent variable Performance is the lagged annual moving average of provincial GDP growth during the tenure of the official that accounts for both the relative performance of other provinces in China and the long-term provincial growth trend of the province to remedy potential endogeneity, ${ }^{29}$ similar to the one used by Shih et al. (2012). Connections is a dummy variable that equals 1 if the official shared birth, college, or work experience with Deng Xiaoping (1990-1996), Jiang Zemin (1990-2002), or Hu Jintao (2003-2004) or happened to be working in their native provinces, and 0 otherwise. This is coded similarly as in my earlier analysis employing provincial-level data from Shih (2008).

In addition, Age63, Minority, Partyb4work, and Term 2 are dummy variables equaling 1 if the official was above the age of 63 (hence approaching mandatory retirement age), came from an ethnic minority group, joined the CCP before the start of his professional career (and thus possibly more ideologically committed), and had already served at the job for more than 5 years, respectively, 0 otherwise. Education, 0 for an official with no college, 1, 2, 3, and 4, respectively, for one with an associate degree (dazhuan), college, master's or postgraduate degree, and doctorate, controls for their educational credentials. Non-CC and Alternate CC are dummy variables indicating the existing membership status of the official in the CCP Central Committee, as noted above. ${ }^{30}$ I finally add several provincial-level variables, all lagged by 1 year, that could influence provincial economic growth - Per Capita GDP, the natural log of provincial per capita GDP (at constant $1977 \mathrm{RMB}$ ), Investment, growth in real total investment in fixed assets, and Exports, the share of provincial exports in provincial GDP, as well as a full set of province and year dummy variables. I use a linear probability model and report the results in Table 6.

Model 1 includes the period from 1990 (as Jiang Zemin became the chief of CCP in the second half of 1989) to 2004. Model 2 only includes data for 1990-2002 as Hu Jintao took over as the CCP General Secretary in late 2002. Model 3 covers data for 1994-2004, the sample period for the analysis of this study. As we can see, provincial economic growth during their tenure is not a significant predictor of promotion to Politburo membership for the provincial party secretaries. If anything, the coefficient of Performance is negative, but it has not attained any conventional level of statistical significance. Meanwhile, the negative and significant (at 0.01 ) coefficient of Alternate CC across all models suggests provincial party chiefs were less likely to gain a Politburo seat without joining the full CC membership

\footnotetext{
${ }^{27}$ I thank the editors and a reviewer for suggesting the need for addressing this possible concern.

${ }^{28}$ See Sheng (2018) for a critical review and empirical reassessment of the thesis and for the coding of the main independent variable Performance, and more details on the individual-level data used for analysis reported below.

${ }^{29}$ I use the provincial moving average GDP growth rate as of the year prior to the official's first appointment, equivalent to the long-term growth trend established by the official's predecessors since 1978, the first year of reform.

${ }^{30}$ They equal 1 if the official was not a member of the Central Committee or if the official was only an alternate member of the Central Committee, 0 otherwise. The excluded category is for full CC members who were not Politburo members (Politburo members are full CC members first).
} 
Table 6. Economic performance and Politburo promotion: individual-level analysis

\begin{tabular}{|c|c|c|c|c|c|c|}
\hline & \multicolumn{2}{|c|}{ Model 1 (1990-2004) } & \multicolumn{2}{|c|}{ Model 2 (1990-2002) } & \multicolumn{2}{|c|}{ Model 3 (1994-2004) } \\
\hline & Coefficient & S.E. & Coefficient & S.E. & Coefficient & S.E. \\
\hline Performance & -0.000 & $(0.003)$ & -0.000 & $(0.003)$ & -0.001 & (0.003) \\
\hline Connections & -0.010 & $(0.029)$ & -0.011 & $(0.043)$ & -0.007 & $(0.034)$ \\
\hline Age63 & -0.037 & $(0.028)$ & -0.034 & $(0.033)$ & -0.038 & $(0.032)$ \\
\hline Minority & 0.039 & $(0.079)$ & 0.029 & $(0.087)$ & 0.083 & $(0.114)$ \\
\hline Partyb4work & -0.005 & $(0.028)$ & -0.013 & $(0.033)$ & 0.022 & $(0.032)$ \\
\hline Education & -0.009 & $(0.013)$ & -0.004 & $(0.016)$ & -0.009 & $(0.018)$ \\
\hline Term2 & -0.011 & $(0.023)$ & -0.023 & $(0.028)$ & 0.009 & $(0.032)$ \\
\hline Alternate CC & $-0.120^{\star \star \star}$ & $(0.044)$ & $-0.120^{\star \star \star}$ & $(0.045)$ & $-0.129^{\star \star \star}$ & $(0.049)$ \\
\hline Non-CC & 0.098 & $(0.076)$ & 0.102 & $(0.076)$ & -0.007 & $(0.040)$ \\
\hline Per Capita GDP & -0.051 & $(0.089)$ & -0.031 & $(0.104)$ & 0.041 & (0.146) \\
\hline Investment & 0.000 & $(0.001)$ & 0.000 & $(0.001)$ & 0.000 & (0.001) \\
\hline Exports & $0.007^{\star}$ & $(0.004)$ & $0.010^{*}$ & $(0.006)$ & $0.010^{\star \star}$ & (0.005) \\
\hline Constant & 0.550 & $(0.696)$ & 0.529 & $(0.915)$ & -0.325 & (1.018) \\
\hline Observations & \multicolumn{2}{|c|}{340} & \multicolumn{2}{|c|}{301} & \multicolumn{2}{|c|}{241} \\
\hline Adjusted $R^{2}$ & \multicolumn{2}{|c|}{0.243} & \multicolumn{2}{|c|}{0.246} & \multicolumn{2}{|c|}{0.219} \\
\hline
\end{tabular}

Note: The dependent variable is Promotion, an annual dummy variable indicating whether a provincial party secretary who was not already a Politburo member was promoted to Politburo membership ( $=1$ if yes, and 0 otherwise), and estimated with a linear probability model. Performance is the main independent variable, a lagged moving average of provincial GDP growth during the tenure of the official that accounts for both relative growth of other provinces in China as well as a long-term growth trend of the province, coded according to Sheng (2018). Per Capita GDP, Investment, and Exports are provincial-level variables (all lagged by 1 year) measuring the traits of the province where the official was serving; all other independent variables are individual-level variables (not lagged) capturing the personal characteristics of the official. Model 1 covers 1990-2004; Model 2 covers 1990-2002; and Model 3 covers 1994-2004. See the text for more details on the source and definitions of the other variables used. All estimations include a full set of province and year dummy variables whose results are omitted. Robust standard errors are in parentheses.

${ }^{\star \star \star} P<0.01,{ }^{\star \star} P<0.05,{ }^{\star} P<0.1$.

first. In short, this analysis does not support the notion that the findings could largely reflect the bestowing of Politburo membership on provincial party secretaries boasting a stellar economic performance scorecard.

\subsubsection{Possible structural changes since 2003}

The analysis so far has included fiscal data from 1995 to 2004 (effectively 1996-2004 for analysis due to lagging and first differencing). The data series started in the aftermath of the 1994 fiscal reform under Jiang Zemin who retired as China's commander in chief and its de facto top leader in late 2004. However, $\mathrm{Hu}$ Jintao took over as the national chief of the CCP in late 2002 and later on began to pursue a more regionally redistributive agenda during his tenure, as noted. ${ }^{31}$

To examine whether this possible structural change associated with the transition from Jiang to $\mathrm{Hu}$ was mostly responsible for the results, I add to the baseline Model 1 in Tables 2 and 3 a dummy variable HJT Years that equals 1 for data observed during 2003 and 2004, and 0 otherwise. I then interact it with both the lagged and first-differenced Politburo and re-analyze the data for both dependent variables. The results are reported in Table 7 where Model 1 is for Remittance and Model 2 is for Subsidy. As we can see, neither Politburo $\times H J T$ Years nor $\Delta$ Politburo $\times H J T$ Years is statistically significant at the conventional levels, lending little support to the notion that the effect of the Politburo variable has changed in the post-2002 years.

To sum up, my empirical analysis has shown that Politburo membership for provincial officials was associated with greater provincial budgetary remittances to the central government, but did not seem to be associated with greater central fiscal subsidies for the provinces ruled by the Politburo members. This does not support $\mathrm{Ha}$, but is more consistent with $\mathrm{Hb}$, as suggested by a territorial logic of authoritarian power-sharing.

\footnotetext{
${ }^{31}$ I am grateful to the editors and a reviewer for raising this possible concern.
} 
Table 7. Provincial Politburo representation, central fiscal extraction, and fiscal compensation: testing for possible structural change

\begin{tabular}{|c|c|c|c|c|}
\hline & \multicolumn{2}{|c|}{ Model 1} & \multicolumn{2}{|c|}{ Model 2} \\
\hline & Coefficient & S.E. & Coefficient & S.E. \\
\hline Politburo & $3.258^{\star \star}$ & $(1.328)$ & 1.516 & $(7.746)$ \\
\hline$\Delta$ Politburo & 0.939 & $(0.668)$ & -7.999 & $(7.707)$ \\
\hline HJT Years & $-11.296^{\star \star \star}$ & $(3.075)$ & -22.722 & $(30.280)$ \\
\hline Politburo $\times$ HJT Years & -0.508 & $(1.515)$ & -20.140 & $(13.981)$ \\
\hline$\Delta$ Politburo $\times H J T$ Years & 2.052 & $(2.314)$ & -18.552 & $(15.781)$ \\
\hline Neighbors & -0.014 & $(0.127)$ & 0.076 & $(0.051)$ \\
\hline$\Delta$ Neighbors & -0.004 & $(0.146)$ & $0.327^{\star \star}$ & $(0.143)$ \\
\hline Exports & 0.011 & $(0.086)$ & -0.923 & $(0.691)$ \\
\hline$\Delta$ Exports & -0.013 & $(0.110)$ & -0.846 & $(0.788)$ \\
\hline Connections & 0.399 & $(0.488)$ & 4.398 & (4.462) \\
\hline$\Delta$ Connections & -0.381 & $(0.647)$ & 5.454 & (4.487) \\
\hline Per Capita GDP & $25.585^{\star \star \star}$ & (6.092) & 1.929 & $(46.911)$ \\
\hline$\triangle$ Per Capita GDP & $16.023^{\star}$ & (8.591) & 53.685 & $(81.296)$ \\
\hline Population & 0.511 & $(0.605)$ & $4.961^{*}$ & $(2.938)$ \\
\hline$\Delta$ Population & 0.390 & $(0.479)$ & -0.668 & (2.344) \\
\hline Surplus & $0.009^{\star \star \star}$ & $(0.003)$ & $-0.600^{\star \star \star}$ & $(0.228)$ \\
\hline$\Delta$ Surplus & 0.004 & $(0.004)$ & $-0.592^{\star \star \star}$ & $(0.127)$ \\
\hline Urbanization & -0.034 & $(0.090)$ & -0.379 & $(0.964)$ \\
\hline UUrbanization & -0.042 & $(0.129)$ & -0.711 & $(0.652)$ \\
\hline Remittance & $-0.735^{\star \star \star}$ & $(0.128)$ & & \\
\hline Subsidy & & & $-0.636^{\star \star \star}$ & $(0.223)$ \\
\hline Constant & -55.504 & $(45.830)$ & -31.415 & (425.264) \\
\hline Observations & \multirow{2}{*}{\multicolumn{2}{|c|}{$\begin{array}{c}270 \\
0.592\end{array}$}} & \multirow{2}{*}{\multicolumn{2}{|c|}{$\begin{array}{c}270 \\
0.653\end{array}$}} \\
\hline Adjusted $R^{2}$ & & & & \\
\hline
\end{tabular}

Note: The dependent variable is $\Delta$ Remittance, the annual first difference in provincial per capita budgetary remittances to the central government (1977 RMB) during 1996-2004 in Model 1, and $\Delta$ Subsidy, the annual first difference in central fiscal subsidies (1977 RMB) to each province during 1996-2004 in Model 2. It is estimated with an error correction model. HJT Years is a dummy variable that equals 1 if the year is greater than 2002, 0 otherwise. All other 'level' independent variables are lagged by 1 year. All estimations include a full set of province and year dummy variables whose results are omitted. Robust standard errors are reported in parentheses.

${ }^{* \star \star} P<0.01 ;{ }^{* \star} P<0.05 ;{ }^{\star} P<0.1$ (two-tailed tests).

\section{Conclusion}

Despite the existence of a vibrant literature on how national-level political representation of the subnational units affects resource redistribution among the regions in democracies, we still know little about the regional redistributive consequences of political representation under dictatorship. The logic of authoritarian internal power-sharing within single-party states posits less revenue extraction from or greater fiscal compensation for regions overseen by the allies but potential rivals of the reigning national autocrats sitting in the ruling-party Politburo. An alternative territorial logic of authoritarian power-sharing, in contrast, highlights how selective membership at a collective, decision-making forum such as the Politburo of the single ruling party for subnational officials might induce fiscal compliance and ease central fiscal extraction from the targeted regions without necessarily facilitating inflows of central fiscal largesse. Little empirical work, however, has investigated the possible redistributive consequences of regional political representation under authoritarianism, a task I have taken up in this study.

Drawing on provincial-level data from contemporary China under (so far) relatively resilient CCP single-party rule, I have found robust evidence that provinces ruled by members of the ruling CCP Politburo tended to remit more budgetary revenues to the central government during 1995-2004. The effect of Politburo membership for provincial officials is both statistically and substantively significant. Consistent with the existing studies on the determinants of central fiscal flows to the provinces (Wang, 2004; Fan and Zhang, 2011), Politburo membership for provincial officials, however, did not appear to be associated with greater inflows of fiscal pork (budgetary subsidies) from the central government mostly targeted toward provinces with greater fiscal needs, despite the conventional 
wisdom on Jiang Zemin's regional cronyism and the 'Shanghai gang.' The notion that Politburo membership for provincial leaders can translate into more generous fiscal benefits from the central government for the provinces led by the Politburo members did not seem empirically supported. Furthermore, my results suggest that wealthier Chinese provinces sent more revenues upward while fiscally unhealthier provinces received more central subsidies, suggesting active pursuit of regional redistribution by the central government throughout a period generally known for its excesses of proliberalization policies (Hung, 2015).

For data consistency and due to the need to mitigate possible problems in empirical estimation arising from structural shifts with national leadership transitions, I have confined my study to the years of 1995-2004 largely under the rule of Jiang Zemin. Future work should expand data collection efforts beyond this period to examine whether the same dynamic continues to apply in the era of a worldwide recession and a massive central government stimulus program in China. ${ }^{32}$ In this study, moreover, I have focused on the formal fiscal flows. Future research should also examine how the provincial presence at the CCP Politburo could affect the more informal fiscal and other forms of resource flows between the central and provincial governments once such data become available. It will also be interesting to test these arguments in other settings of authoritarian rule where leaders from the constituent units are seated at a national-level policy forum and where resources flow between the central and the subnational governments.

In a sense, it is perhaps not surprising that there was greater resource extraction from but not greater fiscal compensation for the provinces overseen by members of the CCP Politburo in China. After all, these provincial officials are members of the national autocratic leadership themselves. Seated at a national policy forum within the single-ruling party under authoritarian power-sharing, they are entrusted with the task of ruling the regions on behalf of other colleagues in the Politburo and their senior colleagues in its Standing Committee to whom they are ultimately held accountable. In a democracy, in contrast, more resources tend to flow to constituent units better represented at a higher-level policy-making forum whose members are chosen by, and have incentives to serve the interests of, the local electorates from below. The apparent divergence in the patterns of regional redistributive politics under the two systems thus should not belie the same underlying imperative for political survival that has animated politicians everywhere, democratically elected or otherwise. To the best of my knowledge, nevertheless, this study is the first explicit empirical attempt to study the redistributive consequences of geographic political representation in a nondemocratic setting.

Finally, this study joins a growing body of research in recent years seeking to illuminate the various aspects of authoritarian single-party rule in reform-era China (Landry, 2008; Chen, 2012; Wallace, 2014; Manion, 2015; Dickson, 2016; Truex, 2016), but I have focused on how Politburo membership for provincial officials in the ruling CCP could affect central-provincial fiscal flows. Such authoritarian power-sharing and resource redistribution along the territorial dimension by the CCP national leaders hinges on the institutional tools afforded them by the single ruling party - their predominance within the Politburo and their monopoly personnel powers over the regional government leadership. The story from contemporary China is thus also in keeping with the broader comparative politics research privileging the role of political institutions in the relative durability of single-party authoritarianism around the world (Geddes, 1999; Gandhi and Przeworski, 2007; Magaloni, 2008; Svolik, 2012). Here I have highlighted a territorial dimension of authoritarian power-sharing that is often largely missing in the existing work on the 'varieties' of forms and fates of authoritarianism.

Acknowledgement. For comments and discussions on various aspects of earlier iterations of the paper, I thank Yuen Yuen Ang, Timothy A. Carter, José Cheibub, Qiang Fu, Chris Gelpi, Lei Guang, Grace Huang, Ruixue Jia, John Kennedy, Jean Oi, Tao Sun, Xin Sun, Jessica Teets, Jiangnan Zhu, and seminar and conference participants at Duke University, St. Lawrence University, the University of Michigan, and the annual meeting of the Association of Chinese Political Studies. I have immensely benefited from the insights and suggestions from the reviewers and editors of the Journal, especially Professor

\footnotetext{
${ }^{32}$ Wallace (2014), for example, suggests there was a possible regional pattern in how the central government stimulus money could have been distributed during 2009, but does not examine any provincial role.
} 
Takashi Inoguchi, and the editorial assistance of Ms. Sawaka Ota. I am also grateful to Boliang Zhu for help with the ArcGIS map of Chinese provinces and Shaofeng Chen for assistance with some of the Chinese data sources. I am solely responsible for any remaining errors.

Supplementary material. The supplementary material for this article can be found at https://dataverse.harvard.edu/dataset. xhtml?persistentId=doi:10.7910/DVN/HCYPMB

\section{References}

Ansolabehere S, Gerber A and Snyder J. (2002) Equal votes, equal money: court-ordered redistricting and public expenditures in the American states. American Political Science Review 96, 767-777.

Atlas CM, Gilligan TW, Hendershott RJ and Zupan MA (1995) Slicing the federal government net spending pie: who wins, who loses, and why. American Economic Review 85, 624-629.

Beck N and Katz JN (1995) What to do (and not to do) with time-series cross-section data. American Political Science Review 89, 634-647.

Beck N and Katz JN (2011) Modeling dynamics in time-series-cross-section political economy data. Annual Review of Political Science 14, 331-352.

Beck N, Katz JN and Tucker R (1998) Taking time seriously: time-series-cross-section analysis with a binary dependent variable. American Journal of Political Science 42, 1260-1288.

Berry CR, Burden BC and Howell WG (2010) The president and the distribution of federal spending. American Political Science Review 104, 783-799.

Brownlee J (2007) Authoritarianism in an Age of Democratization. New York: Cambridge University Press.

Bueno de Mesquita B, Smith A, Morrow JD and Siverson RM (2003) The Logic of Political Survival. Cambridge, MA: MIT Press.

Caizhengbu Difangsi [Department of Local Affairs of China Ministry of Finance] (1996) Difang Caizheng Tongji Ziliao 1995. Beijing: Xinhua Chubanshe.

Caizhengbu Difangsi [Department of Local Affairs of China Ministry of Finance] (1998) Difang Caizheng Tongji Ziliao 1996. Beijing: Zhongguo Caizheng Jingji Chubanshe.

Caizhengbu Yusuansi [Department of Budget of China Ministry of Finance] (1998) Difang Caizheng Tongji Ziliao 1997. Beijing: Xinhua Chubanshe.

Caizhengbu Yusuansi [Department of Budget of China Ministry of Finance] (1999) Difang Caizheng Tongji Ziliao 1998. Beijing: Zhongguo Caizheng Jingji Chubanshe.

Caizhengbu Yusuansi [Department of Budget of China Ministry of Finance] (2001a) Difang Caizheng Tongji Ziliao 1999. Beijing: Zhongguo Caizheng Jingji Chubanshe.

Caizhengbu Yusuansi [Department of Budget of China Ministry of Finance] (2001b) Difang Caizheng Tongji Ziliao 2000. Beijing: Zhongguo Caizheng Jingji Chubanshe.

Caizhengbu Guokusi [Department of State Treasury of China Ministry of Finance] and Caizhengbu Yusuansi [Department of Budget of China Ministry of Finance] (2002) Difang Caizheng Tongji Ziliao 2001. Beijing: Zhongguo Caizheng Jingji Chubanshe.

Caizhengbu Guokusi [Department of State Treasury of China Ministry of Finance] and Caizhengbu Yusuansi [Department of Budget of China Ministry of Finance] (2003) Difang Caizheng Tongji Ziliao 2002. Beijing: Zhongguo Caizheng Jingji Chubanshe.

Caizhengbu Guokusi [Department of State Treasury of China Ministry of Finance] and Caizhengbu Yusuansi [Department of Budget of China Ministry of Finance] (2005) Difang Caizheng Tongji Ziliao 2003. Beijing: Zhongguo Caizheng Jingji Chubanshe.

Caizhengbu Guokusi [Department of State Treasury of China Ministry of Finance] and Caizhengbu Yusuansi [Department of Budget of China Ministry of Finance] (2006) Difang Caizheng Tongji Ziliao 2004. Beijing: Zhongguo Caizheng Jingji Chubanshe.

Chang Y (1999) Shirun 'renwushui' de wenti yu duice. Jiangxi Caizheng Shuiwu Zhuanke Xuexiao Xuebao 14-17.

Cheibub JA (1998) Political regimes and the extractive capacity of governments: taxation in democracies and dictatorships. World Politics 50, 349-376.

Chen X (2012) Social Protest and Contentious Authoritarianism in China. New York: Cambridge University Press.

Chung JH (2016) Centrifugal Empire: Central-Local Relations in China. New York: Columbia University Press.

De Boef S and Keele L (2008) Taking time seriously. American Journal of Political Science 52, 184-200.

Dickson BJ (2016) The Dictator's Dilemma: The Chinese Communist Party's Strategy for Survival. New York: Oxford University Press.

Duiwai Jingji Maoyibu [China Ministry of Foreign Trade and Economic Cooperation] (1987-2003) Zhongguo Duiwai Jingji Maoyi Nianjian. Xianggang: Huarun Maoyi Zixun Youxian Gongsi.

Economy EC (2014) China’s imperial President: Xi Jinping tightens his grip. Foreign Affairs 93, 80-91. 
Fan B and Zhang M (2011) Jiyu mianban fengxi de zhongguo shengji xingzheng quyu huoqu zhongyang caizheng zhuanyizhifu de shizheng yanjiu. Zhejiang Daxue Xuebao (Renwen Shehui Kexue Ban) 41, 34-44.

Fewsmith J (2003) The sixteenth national party congress: the succession that didn't happen. China Quarterly 1-16.

Fewsmith J (2004) Promoting the scientific development concept. Chinese Leadership Monitor 1-10. Available at http:// media.hoover.org/sites/default/files/documents/clm11_jf.pdf.

Gandhi J (2008) Political Institutions Under Dictatorship. New York: Cambridge University Press.

Gandhi J and Przeworski A (2006) Cooperation, cooptation, and rebellion under dictatorships. Economics and Politics 18, 1-26.

Gandhi J and Przeworski A (2007) Authoritarian institutions and the survival of autocrats. Comparative Political Studies 40 , 1279-1301.

Geddes B (1999) What do we know about democratization after twenty years? Annual Review of Political Science 2, 115-144.

Gerring J (2007) Is there a (viable) crucial-case method? Comparative Political Studies 40, 231-253.

Green DP, Kim SY and Yoon DH (2001) Dirty pool. International Organization 55, 441-468.

Guojia Tongji Ju [National Bureau of Statistics] (1999) Xinzhongguo wushinian tongji ziliao huibian. Beijing: Zhongguo Tongji Chubanshe.

Guojia Tongji Ju [National Bureau of Statistics] (2000-2005) Provincial Statistical Yearbooks 2000-2004 (Individual Issues for Each Province Covering 1999-2004 Data). Beijing: Zhongguo Tongji Chubanshe.

Guojia Tongji Ju [National Bureau of Statistics] (2005) Zhongguo tongji nianjian 2005. Beijing: Zhongguo Tongji Chubanshe.

Harasymiw B (1969) Nomenklatura: the soviet communist party's leadership recruitment system. Canadian Journal of Political Science 2, 493-512.

Heckman JJ (1979) Sample selection bias as a specification error. Econometrica 47, 153-161.

Horiuchi Y and Saito J (2003) Reapportionment and redistribution: consequences of electoral reform in Japan. American Journal of Political Science 47, 669-682.

Huang Y (1996) Inflation and Investment Controls in China: The Political Economy of Central-Local Relations During the Reform Era. New York: Cambridge University Press.

Huang Y (2002) Managing Chinese bureaucrats: an institutional economics perspective. Political Studies 50, 61-79.

Huang Y and Sheng Y (2009) Political decentralization and inflation: sub-national evidence from China. British Journal of Political Science 39, 389-412.

Hung H-f (2015) The China Boom: Why China Will Not Rule the World. New York: Columbia University Press.

Isenman P (1976) Biases in aid allocations against poorer and larger countries. World Development 4, 631-641.

Jin H, Qian Y and Weingast B (2005) Regional decentralization and fiscal incentives: federalism, Chinese style. Journal of Public Economics 89, 1719-1742.

Kaufman R and Segura-Ubiergo A (2001) Globalization, democratization and social spending in Latin America: a timeseries cross-section analysis, 1973-97. World Politics 53, 553-587.

Keele L and Kelly NJ (2006) Dynamic models for dynamic theories: the ins and outs of lagged dependent variables. Political Analysis 14, 186-205.

Knight B (2008) Legislative representation, bargaining power, and the distribution of federal funds: evidence from the U.S. Senate. Economic Journal 118, 1785-1803.

Kung JK-S and Chen S (2011) The tragedy of the Nomenklatura: career incentives and political radicalism during China's great leap famine. American Political Science Review 105, 27-45.

Lam WW-L (2006) Chinese Politics in the Hu Jintao era: New Leaders, New Challenges. Armonk, NY: M.E. Sharpe.

Landry PF (2008) Decentralized Authoritarianism in China: The Communist Party's Control of Local Elites in the Post-Mao Era. New York: Cambridge University Press.

Lee FE (2000) Senate representation and coalition building in distributive politics. American Political Science Review 94, 59-72.

Levi M (1988) Of Rule and Revenue. Berkeley: The University of California Press.

Li C (2002) The 'Shanghai Gang': force for stability or cause for conflict? China Leadership Monitor 1-18. Available at https:// www.hoover.org/sites/default/files/uploads/documents/clm2_CL.pdf.

Li C (2016) Chinese Politics in the Xi Jinping Era: Reassessing Collective Leadership. Washington, DC: Brookings Institution Press.

Lieberthal KG (2003) Governing China: From Revolution Through Reform, 2nd Edn. New York: W.W. Norton.

Lü X and Landry PF (2014) Show me the money: interjurisdiction political competition and fiscal extraction in China. American Political Science Review 108, 706-722.

Magaloni B (2008) Credible power-sharing and the longevity of authoritarian rule. Comparative Political Studies 41, 715-741.

Malesky E, Schuler P and Tran A (2012) The adverse effects of sunshine: a field experiment on legislative transparency in an authoritarian assembly. American Political Science Review 106, 762-786.

Manion M (1993) Retirement of Revolutionaries in China: Public Policies, Social Norms, Private Interests. Princeton: Princeton University Press.

Manion M (2015) Information for Autocrats: Representation in Chinese Local Congresses. New York: Cambridge University Press. 
Naughton BJ and Yang DL (eds) (2004) Holding China Together: Diversity and National Integration in the Post-Deng Era. New York: Cambridge University Press.

O’Brien KJ (1990) Reform Without Liberalization: China's National People's Congress and the Politics of Institutional Change. New York: Cambridge University Press.

Rodden J (2002) Strength in numbers? Representation and redistribution in the European Union. European Union Politics 3 , 151-175.

Samuels D and Snyder R (2001) The value of a vote: malapportionment in comparative perspective. British Journal of Political Science 31, 651-671.

Shambaugh DL (2003) Modernizing China's Military: Progress, Problems, and Prospects. Berkeley: University of California Press.

Shangwubu [China Ministry of Commerce] (2004-2005) Zhongguo Shangwu Nianjian. Beijing: Zhongguo Shangwu Chubanshe.

Sheng Y (2005) Central-provincial relations at the CCP central committees: institutions, measurement and empirical trends, 1978-2002. The China Quarterly, 338-355.

Sheng Y (2009) Authoritarian co-optation, the territorial dimension: provincial political representation in post-Mao China. Studies in Comparative International Development 44, 71-93.

Sheng Y (2010) Economic Openness and Territorial Politics in China. New York: Cambridge University Press.

Sheng Y (2018) How Has China's Performance-Based Authoritarianism Worked?: GDP Growth and the Political Fortunes of the Provincial Leaders During the Reform Era. Unpublished Working Paper, Department of Political Science, Wayne State University, Detroit, Michigan, USA.

Shih VC (2008) Factions and Finance in China: Elite Conflict and Inflation. New York: Cambridge University Press.

Shih V, Adolph C and Liu M (2012) Getting ahead in the communist party: explaining the advancement of central committee members in China. American Political Science Review 106, 166-187.

Shirk SL (1993) The Political Logic of Economic Reform in China. Berkeley: University of California Press.

Svolik MW (2009) Power sharing and leadership dynamics in authoritarian regimes. American Journal of Political Science 53, 477-494.

Svolik MW (2012) The Politics of Authoritarian Rule. Cambridge: Cambridge University Press.

Truex R (2016) Making Autocracy Work: Representation and Responsiveness in Modern China. New York: Cambridge University Press.

Unger J and Dittmer (L) (eds) 2002. The Nature of Chinese Politics: From Mao to Jiang. Armonk: M.E. Sharpe.

Wallace JL (2014) Cities and Stability: Urbanization, Redistribution, and Regime Survival in China. New York: Oxford University Press.

Wang S (1997) China's 1994 fiscal reform: an initial assessment. Asian Survey 37, 801-816.

Wang S (2004) For national unity: the political logic of fiscal transfer in China. In Liew LH and Wang S. Nationalism, Democracy and National Integration in China. New York: RoutledgeCurzon, pp. 221-246.

Wang $\mathbf{Z}$ and Vangeli A (2016) The rules and norms of leadership succession in China: from Deng Xiaoping to Xi Jinping and Beyond. The China Journal 24-40.

White LT (1989) Shanghai Shanghaied?: Uneven Taxes in Reform China. Hong Kong: Centre of Asian Studies, University of Hong Kong.

Whiting SH (2001) Power and Wealth in Rural China: The Political Economy of Institutional Change. New York: Cambridge University Press.

Wong CPW, Heady C and Woo WT (1995) Fiscal Management and Economic Reform in the People's Republic of China. Hong Kong: Oxford University Press.

Wright J (2008) Do authoritarian institutions constrain? How legislatures affect economic growth and investment. American Journal of Political Science 52, 322-343.

Xia M (2008) The People's Congresses and Governance in China: Toward a Network Mode of Governance. New York: Routledge.

Yang B and Jiao W (2001) Guo di shui jigou fenshe cunzaide wenti ji duice. Shuiwu Yu Jingji 28-30.

Zeng Q (2018) Party institutions and authoritarian power-sharing: evidence from China's provincial leader appointment. Japanese Journal of Political Science 19, 173-196.

Zhao Y (2003) Fenshuizhi juece Beijing huifang. Liaowang Xinwen Zhoukan 37, 20-29.

Zheng X, Li F, Song S and Yu Y (2013) Central government's infrastructure investment across Chinese regions: a dynamic spatial panel data approach. China Economic Review 27, 264-276.

Zhongguo Caizheng Nianjian Bianji Weiyuanhui [Editorial Committee of Finance Yearbook of China] (1996) Zhongguo Caizheng Nianjian. Beijing: Zhongguo Caizheng Zazhishe.

Zhongguo Caizheng Nianjian Bianji Weiyuanhui [Editorial Committee of Finance Yearbook of China] (1997-2004) Zhongguo Caizheng Nianjian (Individual Issue for Each Year Covering Data for 1996-2003). Beijing: Zhongguo Caizheng Zazhishe. 
Zhongguo Caizheng Nianjian Bianji Weiyuanhui [Editorial Committee of Finance Yearbook of China] (2005) Zhongguo Caizheng Nianjian. Beijing: Zhongguo Caizheng Zazhishe.

Zhongguo Caizheng Nianjian Bianji Weiyuanhui [Editorial Committee of Finance Yearbook of China] (2007-2012) Zhongguo caizheng nianjian (Individual Issue for Each Year Covering Data for 2006-2011). Beijing: Zhongguo Caizheng Zazhishe.

Yumin Sheng, with a Ph.D. in political science from Yale University (2005), is an associate professor of political science at Wayne State University in Detroit, Michigan, USA. His major research interests are elite patronage politics, economic globalization and domestic politics, federalism and decentralization, and regional political representation and resource redistribution under authoritarianism, with a focus on contemporary China. He is the author of Economic Openness and Territorial Politics in China (Cambridge University Press, 2010). His other work has also appeared in British Journal of Political Science, Comparative Political Studies, Journal of Contemporary China, Studies in Comparative International Development, and The China Quarterly.

Cite this article: Sheng Y (2019). The regional consequences of authoritarian power-sharing: Politburo representation and fiscal redistribution in China. Japanese Journal of Political Science 20, 162-189. https://doi.org/10.1017/S1468109919000069 